Review Article

\title{
Botanical and Traditional Uses and Phytochemical, Pharmacological, Pharmacokinetic, and Toxicological Characteristics of Ziziphi Spinosae Semen: A Review
}

\author{
Su-Rong He, ${ }^{1}$ Chong-Bo Zhao $\mathbb{D}^{1},{ }^{1}$ Jing-Xia Zhang, ${ }^{1}$ Jing Wang, ${ }^{1}$ Bo Wu, ${ }^{1,2}$ \\ and Chun-Jie Wu $\mathbb{D}^{2}$ \\ ${ }^{1}$ College of Pharmacy, Shaanxi University of Chinese Medicine, Xianyang 712046, China \\ ${ }^{2}$ College of Pharmacy, Chengdu University of Traditional Chinese Medicine, Chengdu 611137, China \\ Correspondence should be addressed to Chong-Bo Zhao; zhao_chongbo@126.com and Chun-Jie Wu; 3096880484@qq.com
}

Received 4 March 2020; Revised 7 May 2020; Accepted 15 May 2020; Published 10 July 2020

Academic Editor: Filippo Maggi

Copyright (c) 2020 Su-Rong He et al. This is an open access article distributed under the Creative Commons Attribution License, which permits unrestricted use, distribution, and reproduction in any medium, provided the original work is properly cited.

\begin{abstract}
Ziziphi Spinosae Semen (ZS, the seeds of Ziziphus jujuba Mill. var. spinosa (Bunge) Hu ex H. F. Chou) is used as a traditional Chinese medicine referred to as Suan zao ren (酸麥仁). This paper aims to provide a systematic review of its traditional uses and its botanical, phytochemical, pharmacological, pharmacokinetic, and toxicological characteristics. The future development and research prospects for $Z S$ have also been discussed in detail. To date, over 150 compounds have been identified in this plant, including terpenoids, alkaloids, flavonoids, fatty acids, volatile oils, polysaccharides, and others. Both extracts and purified compounds have excellent biological activities, especially sedative and hypnotic effects. Other effects include ameliorating effect of learning and memory, anti-inflammation, antioxidation, blood pressure and lipid lowering, antiaging, and antitumor effects. Thus, this traditional Chinese medicine can be used to treat many diseases such as insomnia, forgetfulness, headaches, and dizziness. Although many of the traditional uses of ZS are well established, the relationship between structure and function still needs to be further studied. In order to better pave the way for research and the establishment of quality control standards for ZS, it will be very important to elucidate its pharmacological mechanisms of action and explore new clinical effects.
\end{abstract}

\section{Introduction}

Ziziphi Spinosae Semen (ZS) has a long history as an effective traditional Chinese medicine [1]. ZS mainly grows in Asia, Europe, Australia, and especially in the inland areas of northern China. ZS tree is a relatively common wild resource in northern China. There has been a saying that "thorns are everywhere" since ancient times. For this reason, the tree of ZS was also commonly known as a "thorn" in ancient China [2].

Presently, more than 30 prescriptions for ZS are listed in the Pharmacopoeia of the People's Republic of China (ChP). These prescriptions have been used to treat palpitations, insomnia, dizziness, headache, nausea and vomiting, coughs, depression, anxiety, and other diseases. More than 150 compounds have been isolated from ZS, including terpenoids, alkaloids, flavonoids, fatty acids, volatile oils, polysaccharides, and some inorganic compounds [3-5]. Moreover, numerous researchers have been found that ZS has a wide range of pharmacological activities including ameliorating effect of learning and memory, anti-inflammatory, antioxidant, antihypertensive, hypolipidemic, antiaging, and anticancer properties $[5,6]$. ZS is mainly used for medicinal purposes.

In this review, we collected the relevant literature, ancient books, and Ph.D. and MSc dissertations related to ZS from a range of scientific databases including PubMed, Baidu Scholar, Vepsa, Wanfang Med Online, CNKI, and others and have summarized the various aspects of $\mathrm{ZS}$, such as its traditional uses and its botanical, phytochemical, pharmacological, pharmacokinetic, and toxicological characteristics. Finally, current problems and research directions for ZS have also been discussed in this paper. 


\section{Botanical Characteristics}

Ziziphus jujuba Mill. var. spinosa (Bunge) Hu ex H. F. Chou (Rhamnaceae) is a deciduous shrub or small arbor approximately 1-3 $\mathrm{m}$ in height (Figure 1). It is a kind of drupe; seeds (ZS) are often used as medicinal parts in traditional medicine.

Older branches are brown, and younger branches are green. The stems are branched, with straight or curved prickles. The leaves are typically $2.5-5 \mathrm{~cm}$ long and $1.2-3 \mathrm{~cm}$ wide, with the color varying from light to dark green. The flowers are small and yellow-green with 2 3 clusters of leaf axils. The calyces contain five lobes and an oval triangle. Every flower has five petals and five stamens. The petals are small and yellowish green in color and alternate with the sepals. The stamens and petals grow opposite to each other. The flower disks are very evident and contain 10 lobes. The ovary is oval and is buried in the flower disk and has two lobes. The fruits are oblate or oval, $6-8 \mathrm{~mm}$ in diameter, and $3 \mathrm{~mm}$ in thickness. Before maturity, the surface of the fruit is smooth and green colored, whereas the mature fruit is purplish red colored. One side of the fruit is flatter than the other and has a slightly uplifted longitudinal line in the center; the other side appears as a bulge. The fruit tastes soursweet and has a light odor. The fruits are harvested between September and October. After harvest, they are typically soaked overnight and the flesh is removed before separating the seed, after which the core shell is crushed and the kernel is removed and sun-dried [5,7]. Although ZS tree is native to China, it is now cultivated in other Asian countries, Europe, and Australia. It is widely distributed in the Chinese provinces of Shandong, Shaanxi, Hebei, Liaoning, Henan, Shanxi, and Gansu, among which Hebei and Shaanxi province are the largest producers and are famous for their high production and quality $[1,8,9]$.

\section{Traditional Uses}

The cultivation of ZS tree has a history of nearly 2000 years. Particularly in the Loess Plateau of China, clusters of ZS tree have been growing since ancient times, and there is one of the oldest ZS trees which has been growing for more than 2000 years in Shanxi Province of China. ZS can be used as effective medicine to nourish the brain and promote hemogenesis, and it is the first type of fruits that can be used for medicinal purposes and as a food that has been promulgated by the Ministry of Health [10]. ZS was first described in "Shen Nong's herbal classic" (the earliest Traditional Chinese Medicine (TCM) monograph during the Eastern Han Dynasty) under the name "Suanzao." Medical books about ZS first appeared in "ShanghanZabingLun" (Eastern Han Dynasty) which was famous for the decoction of spine date seeds, and "Suanzaoren" was first listed in "Materia Medica ChengyaBanju." Therefore, ZS has more than 1700 years of medicinal history. In "Chinese Materia Medica," ZS trees were referred to as "Qi," "Jing," "Shanzao," and "Yezao" [11]. In ancient China, people discovered its ability to eliminate disease and prolong life, and it was used as herbal medicine in successive dynasties after the Tang Dynasty. "Ben Cao Shu Gou Yuan" stated that ZS trees were used as medicines in "Shen Nong's herbal classic" (Qing Dynasty), but, currently, the seeds (ZS) are used as a traditional Chinese medicine [7]. "Shen Nong's herbal classic" gave ZS a top grade and noted that it is an effective medicine for regulating the five Zang organs (heart, lungs, kidneys, liver, and spleen) and longevity [8]. It is usually stir-fried, especially for the treatment of sedation and hypnosis [9]. "Ben Cao Bian Du” noted that fried ZS can cure insomnia of colic asthenia and raw ZS can cure sleepiness caused by colic heat. In addition, according to "Bie Lu" (Western Han Dynasty), ZS could treat cold sweat and polydipsia. "Ben Cao Zai Xin" described the qi and hidroschesisas tringing function of $\mathrm{ZS}$, in addition to benefiting ambition and nourishing the ear and eye [11]. It also was used to treat painful limbs and dampness syndromes in "Shen Nong's herbal classic."

Currently, ZS is an important Chinese medicine for the treatment of insomnia clinically. It can also be used to treat palpitations, dizziness, dietary intolerance, nausea and vomiting, coughs, and other diseases. Spine date seed decoction, a classical clinical prescription, can be used to treat many diseases, including psychiatric disorders such as depression and anxiety, neurological disorders such as headache and vertigo, and circulatory diseases [12]. There are many prescriptions recorded in the ChP such as pills, tablets, capsules, and granules, with pills and tablets being the most commonly used. Among the prescriptions for palpitation and insomnia, ZS is the main medicine, while the prescriptions for other diseases are relatively minor. Moreover, the high nutritional value of ZS makes it indispensable in the health beverage industry. Beverages made from ZS are considered nourishing and strengthening. Common drinks made from ZS include wine, juice, and syrup [13].

\section{Phytochemistry}

The chemical composition of ZS is extremely complex. It has been studied for more than 30 years. Over 150 different chemical components, including terpenoids, alkaloids, flavonoids, fatty acids, volatile oils, and polysaccharides, have been isolated and identified (Figure 2). The specific chemical structures are shown in Figures 3-8. The chemical compositions and corresponding structures of ZS have been comprehensively discussed in this paper with references provided for further study and some ideas for future research directions.

4.1. Terpenoids (1-38). The main chemical compositions in ZS are saponins such as jujuboside A (No. 12), jujuboside B (No. 13), and jujuboside C (No. 16), a triterpenoid, which are closely related to the active ingredient saponin in pseudo-ginseng and ginseng. It is generally believed that it is an effective sedative component of ZS and has a strong central inhibitory effect. Jujubosides have been extensively studied. Otsuka et al. first obtained jujuboside A and jujuboside B from a methanol extract of ZS in 1978 [14]. 


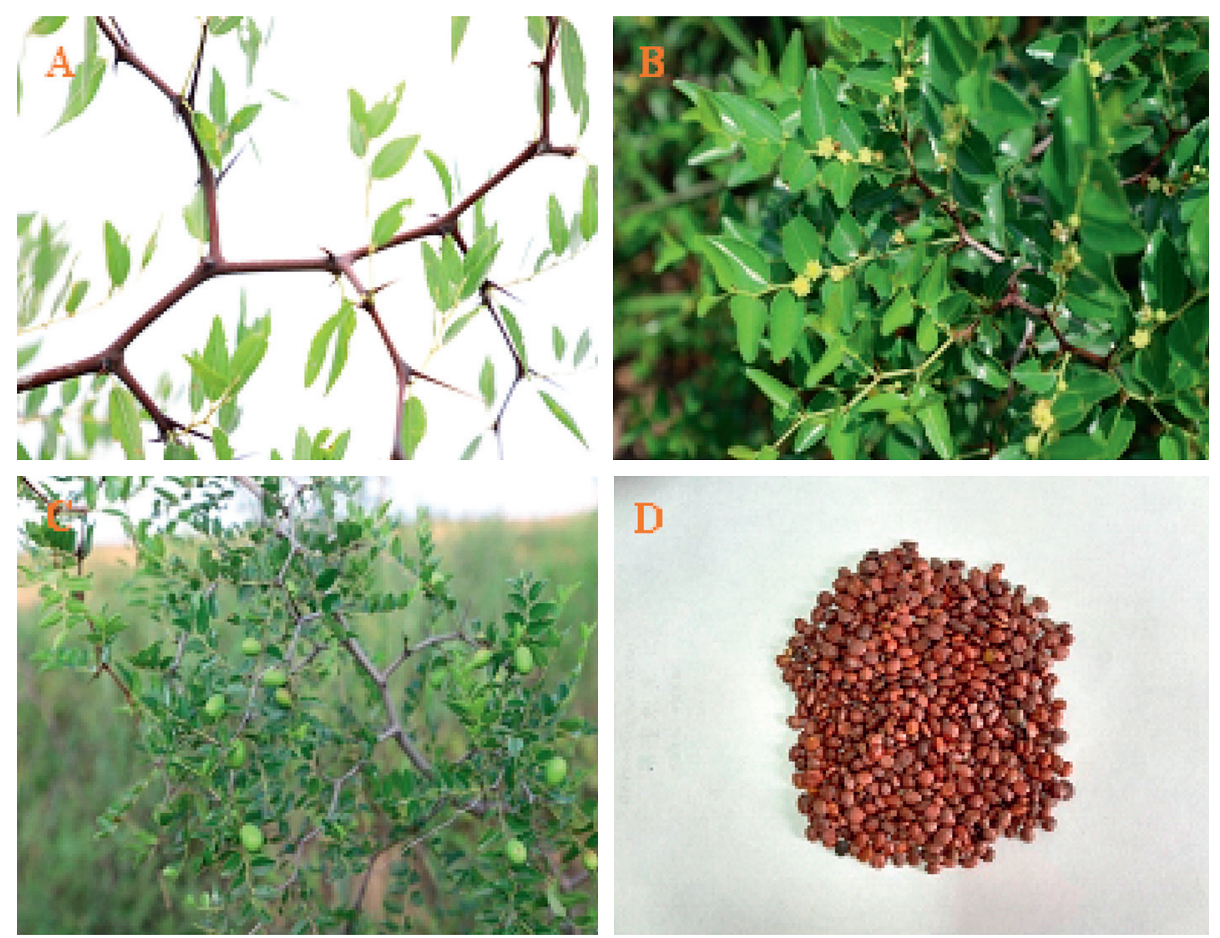

Figure 1: The stem (a), the leaves and flowers (b), the fruits (c), and the seeds (d) from ZS trees.

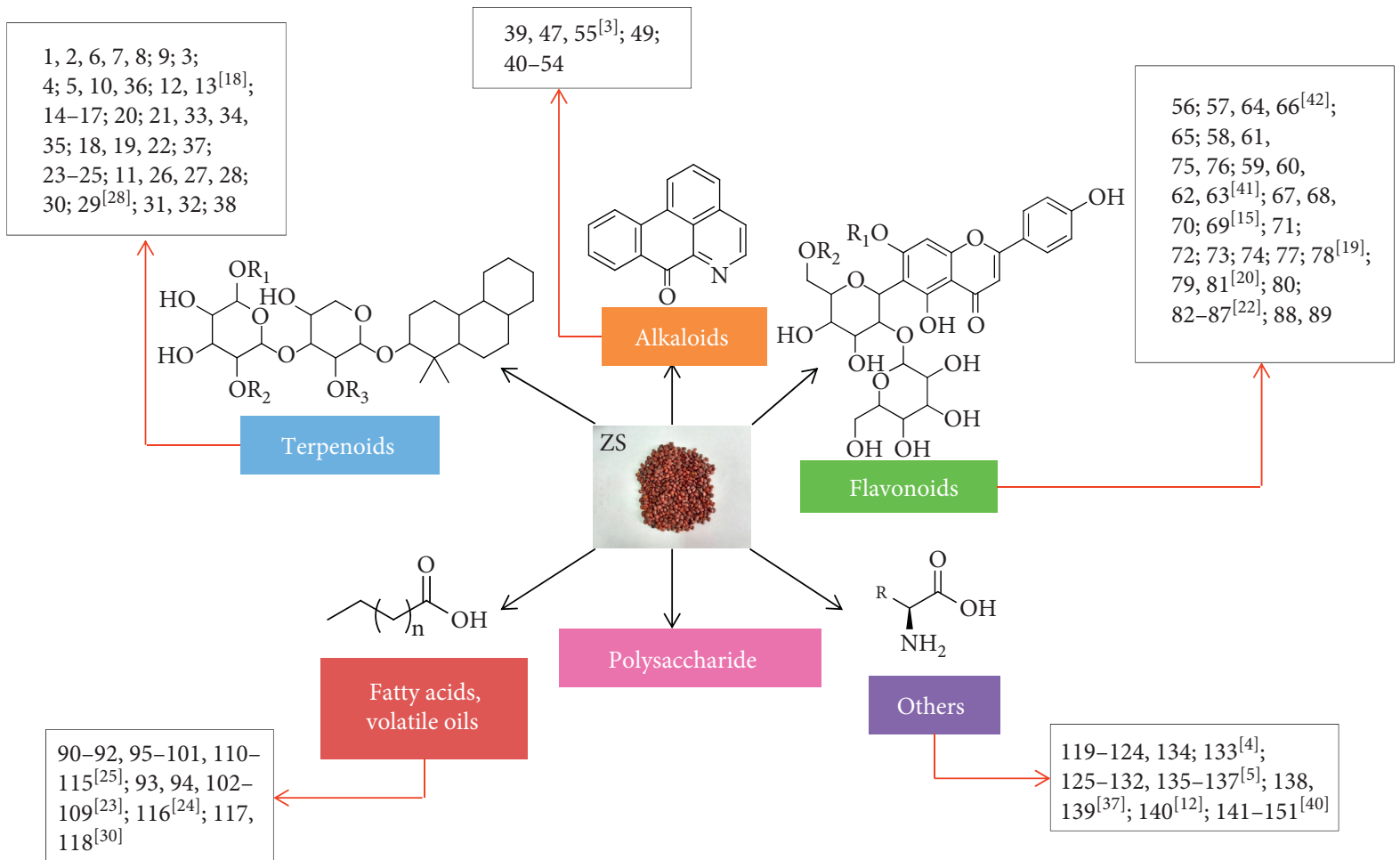

Figure 2: The structure diagram of all the compounds in ZS.

Following this, several other terpenoids were isolated and identified, and currently more than 30 terpenoids have been identified. Their nuclear parents are all of the damaranen type, which is derived from jujubogenin [4].
Lupinane, oleanolic, and ceanothane triterpenoids are the three main triterpenoids found in ZS [3]. The chemical constituents of terpenoids and their corresponding structures are shown in Figure 3. 


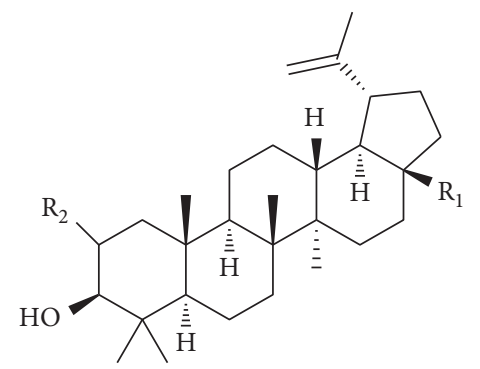

(1) Methyl betulinate: $\mathrm{R}_{1}=\mathrm{COOCH}_{3}$

(2) Lupeol: $\mathrm{R}_{1}=\mathrm{CH}_{3}$

(3) Betulin: $\mathrm{R}_{1}=\mathrm{CH}_{2} \mathrm{OH}$

(4) Betulinic acid: $\mathrm{R}_{1}=\mathrm{COOH}$

(5) Alphitolic acid: $\mathrm{R}_{1}=\mathrm{COOH}, \mathrm{R}_{2}=\mathrm{OH}$

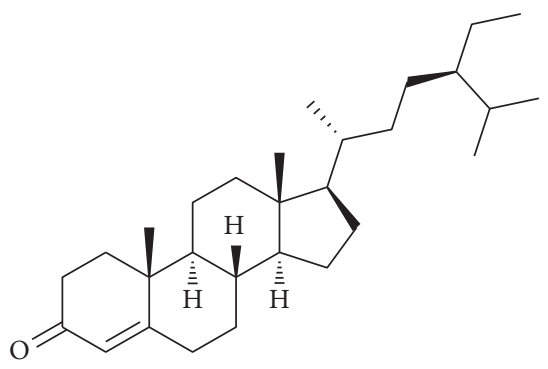

(6) Stigmast-4-en-3-one

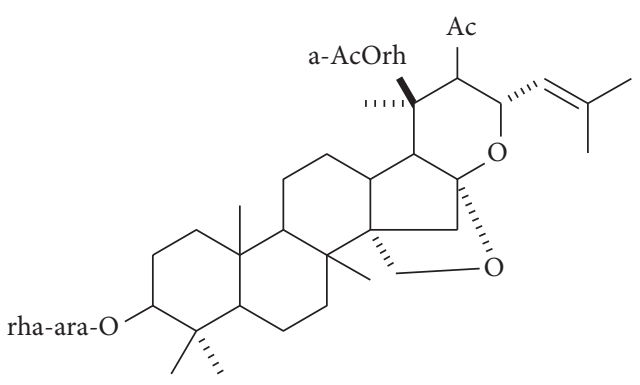

(7) $5 \alpha, 8 \alpha$-Epidioxy- (22E,4R)-ergosta-6, 22-dien- $3 \beta$-ol

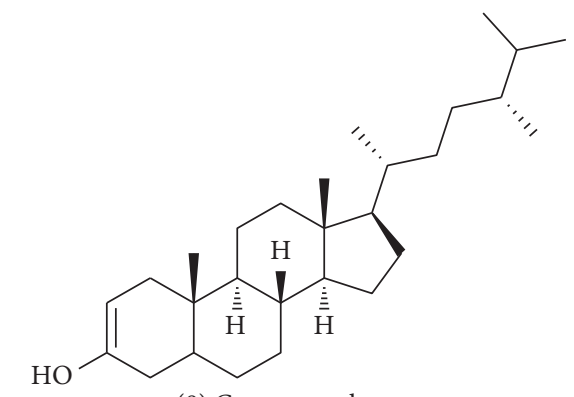

(8) Campesterol<smiles>COc1cc(C(=O)O)ccc1O[C@@H]1O[C@H](CO)[C@@H](O)[C@H](O)[C@H]1O</smiles>

(9) Pseudolaroside B<smiles>C=C(C)C1CC(C(=O)O)C2CCC3(C)C(CCC4C5CCC(C(O)C(C)C3C(=O)O)C4(C)C5(C)C)C12</smiles>

(10) Ceanothic acid<smiles>CC(C)C(C)/C=C/C(C)C1CCC2C34C=CC5(C[C@H](O)CC[C@]3(C)C5CC[C@]12C)OO4</smiles>

(11) Ziziphin

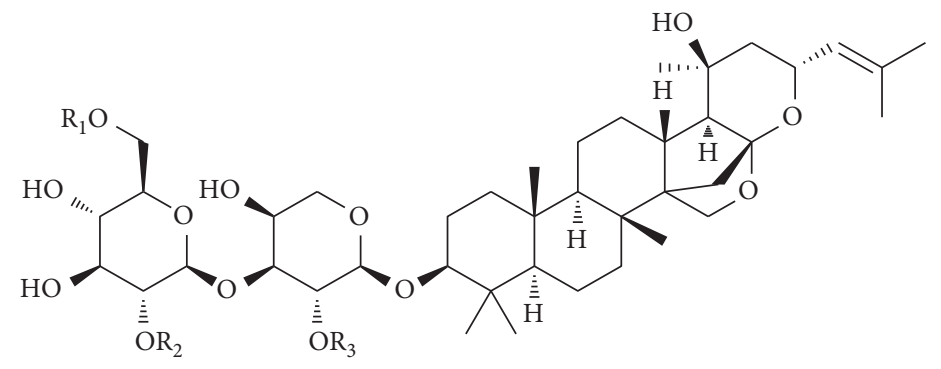

(12) Jujuboside $A: R_{1}=-$ glc, $R_{2}=-x y l, R_{3}=-$ rha

(13) Jujuboside $B: R_{1}=-H, R_{2}=-x y l, R_{3}=-r h a$

(14) Jujuboside A1: $\mathrm{R}_{1}=$-glc, $\mathrm{R}_{2}=$-xyl, $\mathrm{R}_{3}=$-fuc

(15) Jujuboside B1: $\mathrm{R}_{1}=-\mathrm{H}, \mathrm{R}_{2}=$-xyl, $\mathrm{R}_{3}=$-fuc

(16) Jujuboside $C$ : $R_{1}=$-glc, $R_{2}=$-glc, $R_{3}=-$ rha

(17) Acetyljujuboside B: $R_{1}=-A c, R_{2}=-x y l, R_{3}=-$ rha

(18) Zizyphus saponin I: $\mathrm{R}_{1}=-\mathrm{H}, \mathrm{R}_{2}=-\mathrm{H}, \mathrm{R}_{3}=-6$-deoxy-tal

(19) Zizyphus saponin II: $\mathrm{R}_{1}=-\mathrm{H}, \mathrm{R}_{2}=-\mathrm{H}, \mathrm{R}_{3}=$ rha

(20) Zizyphus saponin III: $\mathrm{R}_{1}=-\mathrm{H}, \mathrm{R}_{2}=-\mathrm{xyl}, \mathrm{R}_{3}=-6$-deoxy-tal

(21) Jujuboside $\mathrm{I}: \mathrm{R}_{1}=-\mathrm{H}, \mathrm{R}_{2}=-$ glc, $\mathrm{R}_{3}=-$ glc

(22) Jujuboside A2: $R_{1}=$-glc, $R_{2}=-x y l, R_{3}=-6$-deoxy-tal

Figure 3: Continued. 


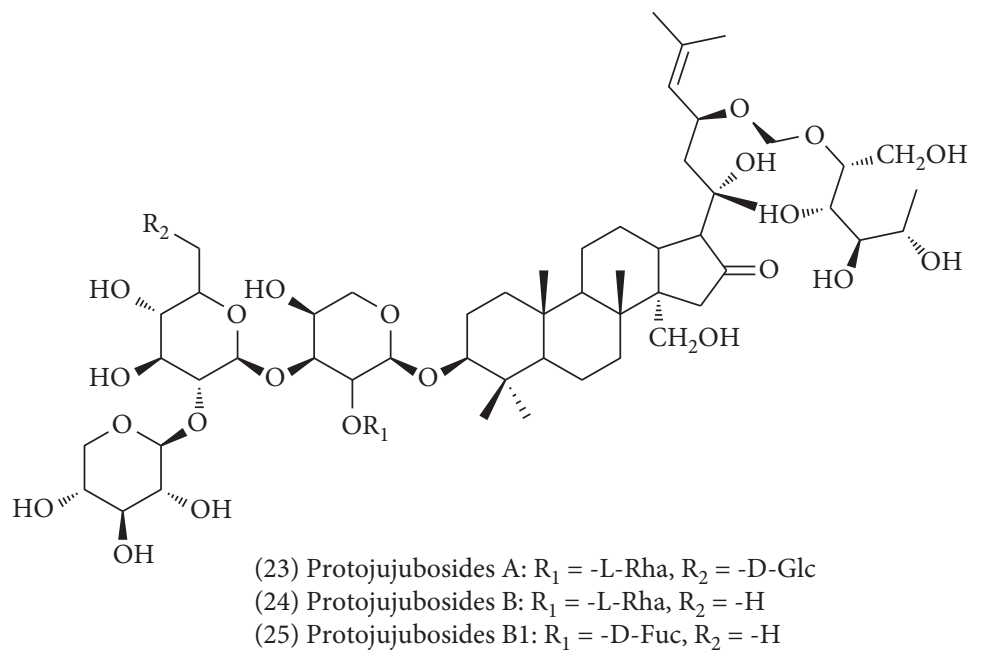

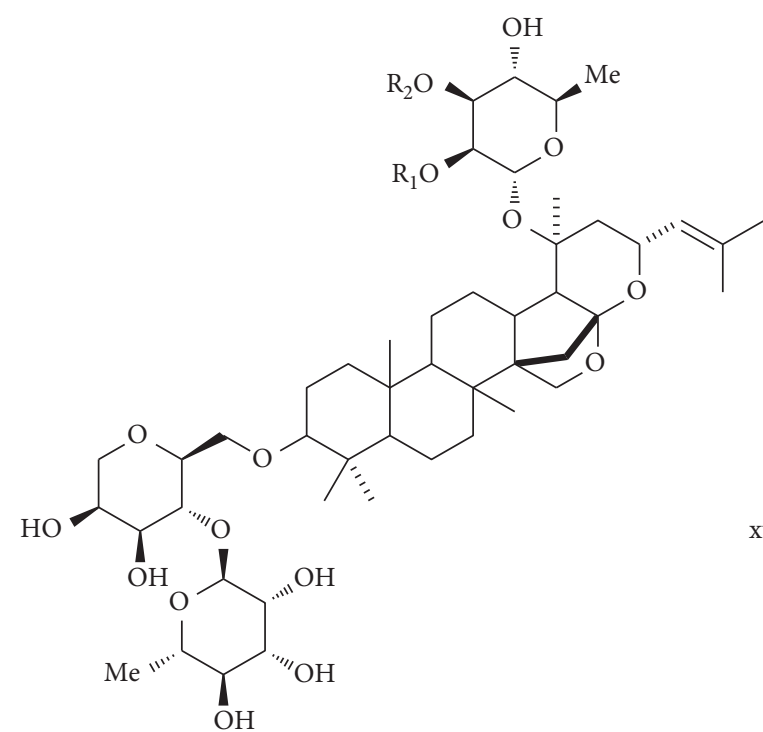

(26) Jujubasaponins I: $\mathrm{R}_{1}=-\mathrm{H} ; \mathrm{R}_{2}=-\mathrm{H}$

(27) Jujubasaponins II: $\mathrm{R}_{1}=-\mathrm{Ac} ; \mathrm{R}_{2}=-\mathrm{H}$

(28) Jujubasaponins III: $\mathrm{R}_{1}=-\mathrm{H} ; \mathrm{R}_{2}=-\mathrm{Ac}$

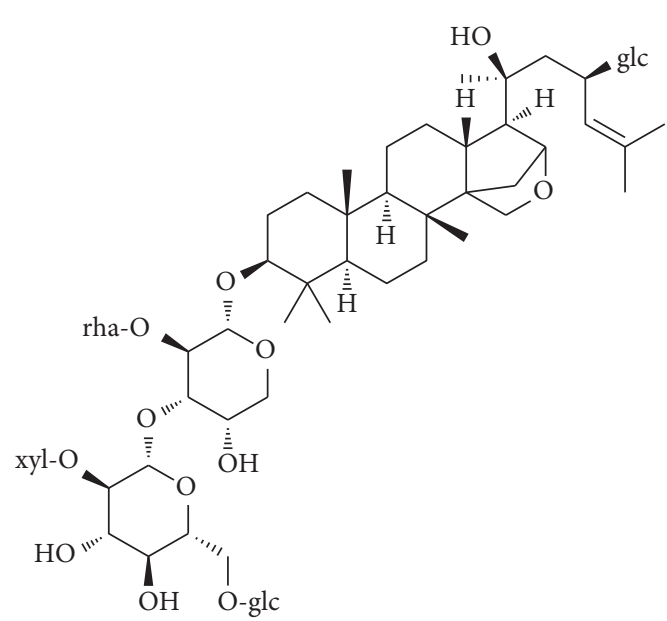

(30) Jujuboside E

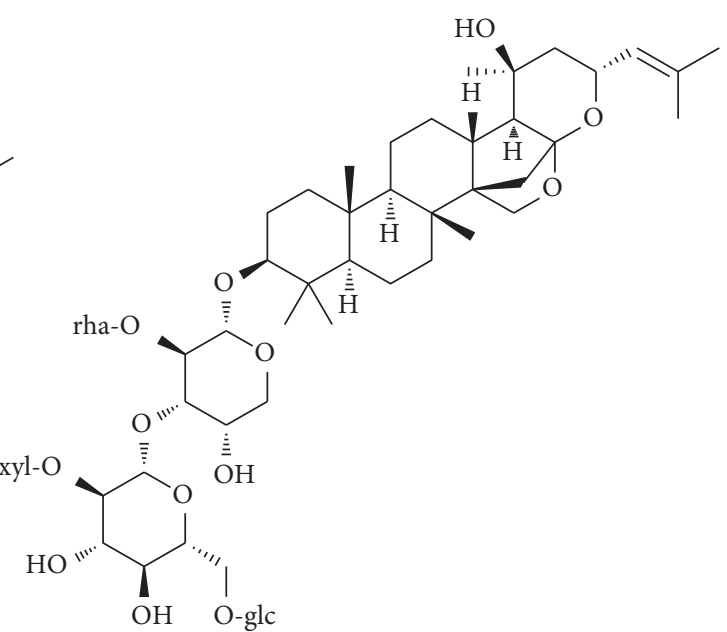

(29) Jujuboside D

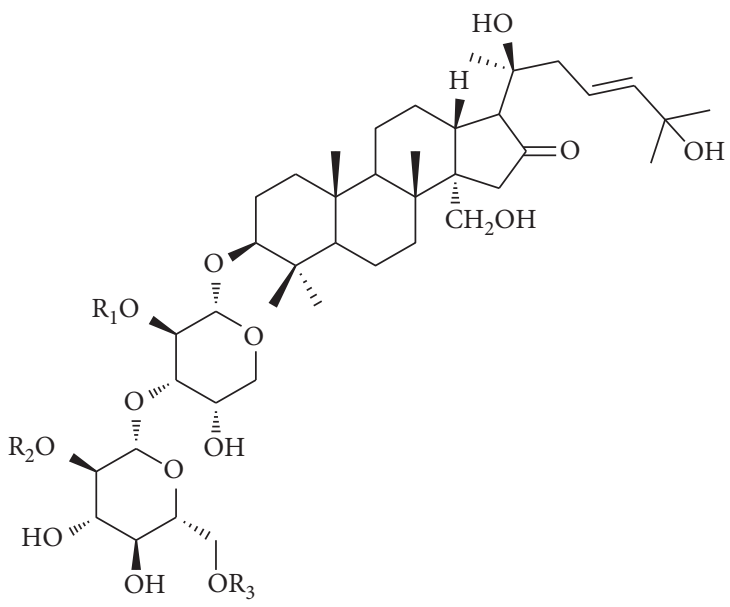

(31) Jujuboside G: $\mathrm{R}_{1}=-\mathrm{rha}, \mathrm{R}_{2}=-\mathrm{xyl}, \mathrm{R}_{3}=-\mathrm{OH}$

(32) Jujuboside $H: R_{1}=-$ rha, $R_{2}=-x y l, R_{3}=-$ glc

Figure 3: Continued. 


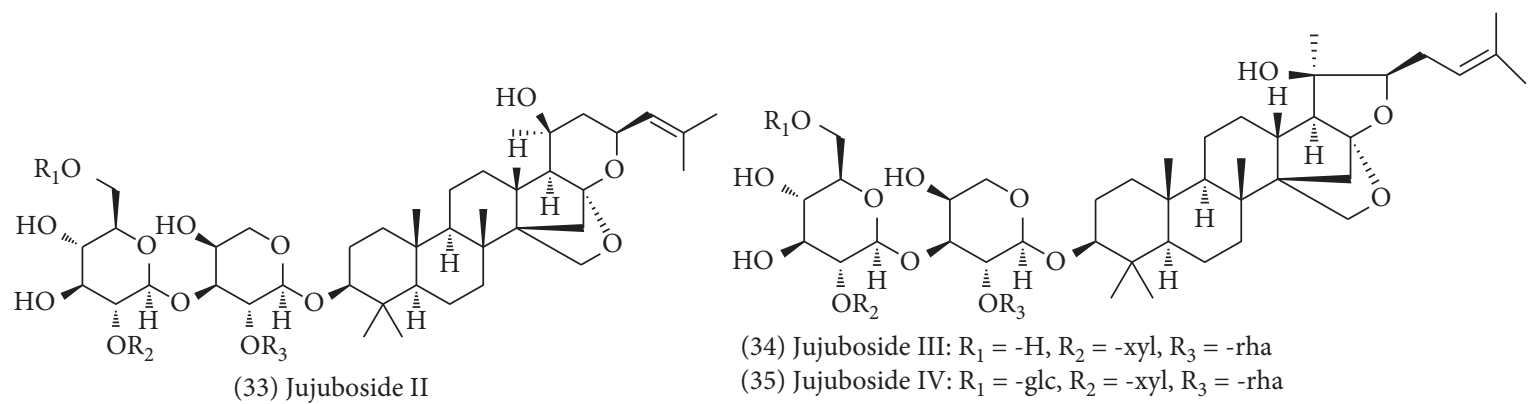

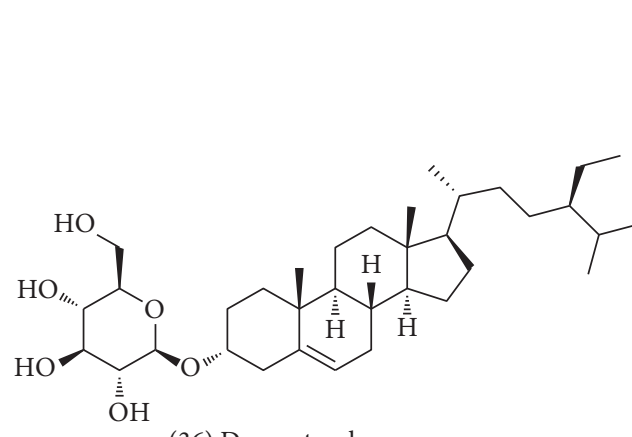

(36) Daucosterol

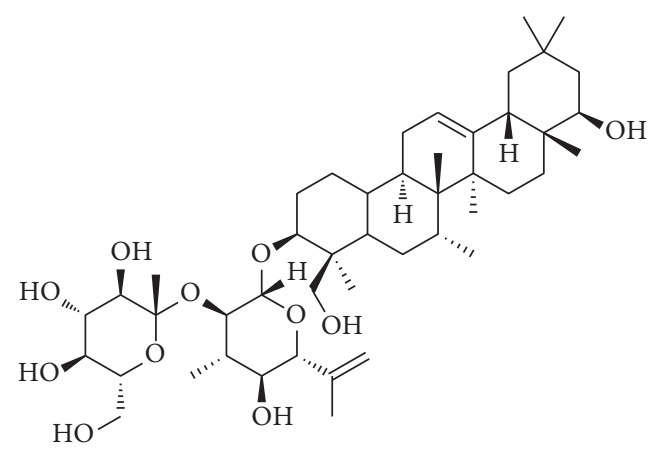

(37) Azukisaponin

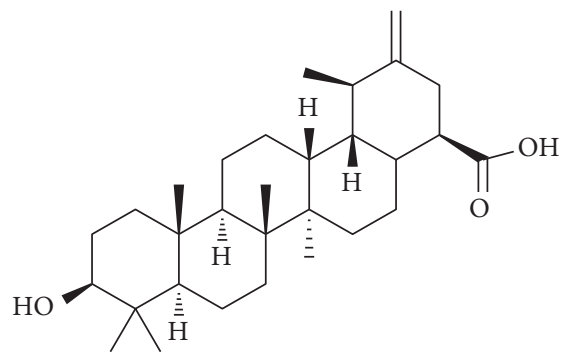

(38) Zizyphursolic acid<smiles>CO[C@H]1O[C@H](CO)[C@@H](O)[C@H](O)[C@H]1O</smiles>

glc<smiles>CO[C@H]1OC[C@@H](O)[C@H](O)[C@H]1O</smiles>

xyl<smiles>C[C@@H]1O[C@H](O[C@H]2O[C@H](C)[C@@H](O)[C@H](O)[C@H]2O)[C@H](O)[C@@H](O)[C@@H]1O</smiles>

fuc<smiles>CO[C@H]1O[C@H](O)[C@@H](O)[C@H](O)[C@H]1C</smiles>

-6-deoxy-tal

FIgure 3: Chemical structures of terpenoids in ZS.

4.2. Alkaloids (39-55). The research level of alkaloids in ZS is far less than that of terpenoids. Two alkaloids, lysicamine and juzirine, were first isolated from ZS by Yin et al. in 1997 [3]. Following this, cyclopeptide alkaloids, such as sanjoinine $G_{1}$ (No. 53) and $G_{2}$ (No. 54), and aporphinoid alkaloids such as sanjoinine E (No. 50), K (No. 45), la (No. 46), and lb (No. 47), were discovered [4]. Sanjoinine E is also known as nuciferine, sanjoinine la is also known as nornuciferine, sanjoinine $\mathrm{lb}$ is also known as norrisocorydine, and sanjoinine $\mathrm{K}$ is also known as coclaurine [5]. In addition, several other alkaloids have also been found in ZS. The chemical constituents of the alkaloids and their corresponding structures are shown in Figure 4.

4.3. Flavonoids (56-89). Flavonoids are one of the main active constituents in ZS and all of them are flavone-Cglycosides. Won et al. first isolated spinosin (No. 66) from methanol extract of ZS in the late 1970s [15]. Following the determination of the structure of flavone-C-glycoside, an increasing number of flavonoids have been isolated and identified. In 1986, zivulgarin (No. 69), a new flavonoid compound was isolated from ZS by Zeng et al. [16]. More 
<smiles>COc1cc2ccnc3c2c(c1OC)-c1ccccc1C3=O</smiles>

(39) Lysicamin<smiles>CC(C)C[C@H](NC(=O)[C@H](NC(=O)[C@@H](Cc1ccccc1)N(C)C)[C@H](OC1=C2C=CC(=CN2)C=C1)C(C)C)C(=O)N[C@@H](Cc1ccccc1)C(C)C</smiles>

(40) Sanjoinine A

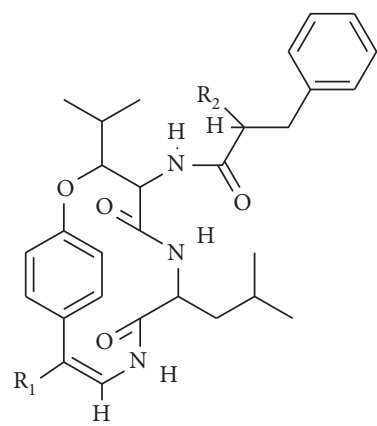

(41) Sanjoinine $B: \mathrm{R}_{1}=\mathrm{H}, \mathrm{R}_{2}=\mathrm{NHCH}_{3}$ (42) Sanjoinine F: $\mathrm{R}_{1}=\mathrm{H}, \mathrm{R}_{2}=\mathrm{N}\left(\mathrm{CH}_{3}\right)_{2}$ (43) Sanjoinenine: $\mathrm{R}_{1}=\mathrm{H}, \mathrm{R}_{2}=\mathrm{H}$<smiles>COC1CNC(=O)C(CC(C)C)NC(=O)C1NC(=O)C(Cc1ccccc1)N(C)C</smiles>

(44) Sanjoinine D<smiles>COc1cc2c(cc1O)[C@H](Cc1ccc(O)cc1)NCC2</smiles>

(45) Sanjoinine K<smiles>[R]c1c(OC)ccc2c1-c1c(OC)cc3c4c1[C@@H](CCN4)NCC32</smiles>

(46) Sanjoinine la: $\mathrm{R}=\mathrm{H}$ (47) Sanjoinine lb: $\mathrm{R}=\mathrm{OH}$<smiles>COc1ccc2c(c1O)-c1c(O)c(O)cc3c1[C@@H](C2)N(C)CC3</smiles>

(48) Zizyphusine: $\mathrm{R}_{1}=\mathrm{CH}_{3}, \mathrm{R}_{2}=\mathrm{H}$ (49) Magnolflorine: $\mathrm{R}_{1}=\mathrm{H}, \mathrm{R}_{2}=\mathrm{CH}_{3}$<smiles>CN1CCc2cc(O)c(O)c3c2[C@@H]1Cc1ccccc1-3</smiles>

(50) Sanjoinine E: $\mathrm{R}_{1}=\mathrm{CH}_{3}, \mathrm{R}_{2}=\mathrm{CH}_{3}, \mathrm{R}_{3}=\mathrm{CH}$ (51) N-methylasimilobine: $\mathrm{R}_{1}=\mathrm{CH}_{3}, \mathrm{R}_{2}=\mathrm{H}, \mathrm{R}_{3}=\mathrm{CH}_{3}$ (52) Caaverine: $\mathrm{R}_{1}=\mathrm{H}, \mathrm{R}_{2}=\mathrm{CH}_{3}, \mathrm{R}_{3}=\mathrm{H}$

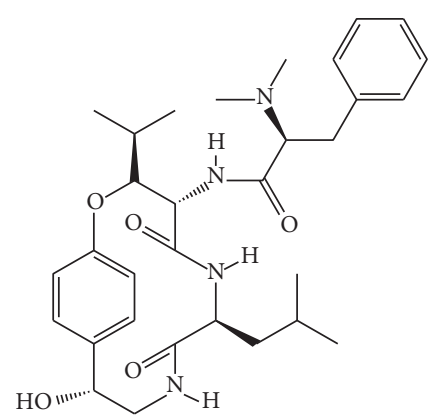

(53) Sanjoinine G1<smiles>CC(C)C[C@H](NC(=O)[C@@H](NC(=O)[C@@H](Cc1ccccc1)N(C)C)[C@H](Oc1ccc(C=O)cc1)C(C)C)C(N)=O</smiles>

(54) Sanjoinine G2<smiles>COc1cc2ccnc(Cc3ccc(O)cc3)c2cc1O</smiles>

(55) Juzirine

FIgURE 4: Chemical structures of alkaloids in ZS.

recently, eight new compounds were isolated for the first time from ZS by Wan et al. in 2008 [17]. Cao et al. isolated seven compounds from ZS, among which quercetin (No. 71) was isolated for the first time $[18,19]$. Currently, more than
20 types of flavonoids have been isolated and identified as the main components responsible for treating sedation and hypnosis. The chemical constituents and their corresponding structures are shown in Figure 5. 


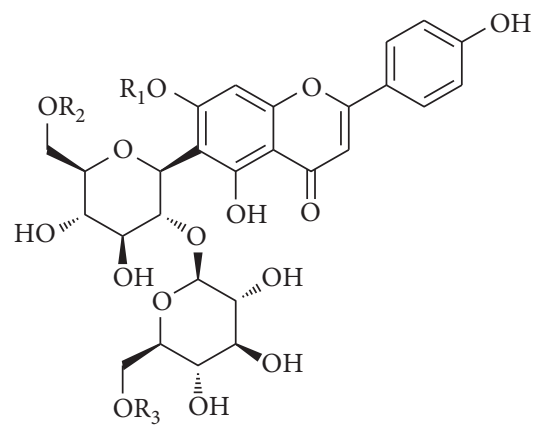

(56) 6", 6"-Diferuloylisospinosin: $\mathrm{R}_{1}=\mathrm{CH}_{3}, \mathrm{R}_{2}=\mathrm{HO} \longrightarrow \mathrm{CH}=\mathrm{CH}-\stackrel{\mathrm{O}}{\mathrm{C}}-, \mathrm{R}_{3}=$<smiles>COc1cc(O)cc(C=CC(C)=O)c1</smiles>

(57) 6"'-Sinapoylspinosin: $\mathrm{R}_{1}=\mathrm{CH}_{3}, \mathrm{R}_{2}=\mathrm{H}, \mathrm{R}_{3}=\mathrm{HO}$

(58) 6"'t-Feruloylspinosin: $\mathrm{R}_{1}=\mathrm{CH}_{3}, \mathrm{R}_{2}=\mathrm{H}, \mathrm{R}_{3}=\mathrm{HO} \longrightarrow \mathrm{CH}=\mathrm{CH}-\stackrel{\mathrm{O}}{\mathrm{C}}-$

(59) 6"' -p-coumaroylspinosin: $\mathrm{R}_{1}=\mathrm{CH}_{3}, \mathrm{R}_{2}=\mathrm{H}, \mathrm{R}_{3}=\mathrm{HO} \longrightarrow \mathrm{CH}=\mathrm{CH}-\mathrm{C}$

(60) 6"'-p-hydroxybenzoylspinosin: $\mathrm{R}_{1}=\mathrm{CH}_{3}, \mathrm{R}_{2}=\mathrm{H}, \mathrm{R}_{3}=\mathrm{HO}$

(61) Isovitexin-2"-O- $\beta$-D-glc: $\mathrm{R}_{1}=\mathrm{H}, \mathrm{R}_{2}=\mathrm{H}, \mathrm{R}_{3}=\mathrm{H}$

(62) $6^{\prime \prime \prime}$ - $\left(4^{\prime \prime \prime}\right.$-O- $\beta$-D-glucopyranosyl-vanilloylspinosin: $\left.\mathrm{R}_{1}=\mathrm{CH}_{3}, \mathrm{R}_{2}=\mathrm{H}, \mathrm{R}_{3}={ }_{\text {glc-O }}^{\mathrm{H}_{3} \mathrm{CO}}\right\rangle=\underset{\mathrm{C}}{\mathrm{O}}$<smiles>COc1cc2oc(-c3ccc(O)cc3)cc(=O)c2c(O)c1[C@H]1O[C@H](CO)[C@@H](O)[C@H](O)[C@H]1O</smiles>

(63) Swertisin

(64) Isospinosin<smiles>[R]OC[C@H]1O[C@H](O[C@H]2[C@@H](c3c(OC)cc4oc(-c5ccc(O)cc5)cc(=O)c4c3O)O[C@H](CO)[C@@H](O)[C@H]2O)[C@H](O)[C@@H](O)[C@@H]1O</smiles>

Figure 5: Continued. 
(65) 6"'-Dihydrophaseoylspinosin: R =<smiles>CC(=O)/C=C(C)/C=C/C12CCCC(C)(CCC1)C2(C)C</smiles>

(66) Spinosin: $\mathrm{R}=\mathrm{H}$<smiles>C[C@@H]1O[C@H](O)[C@H](O)[C@H](O)[C@H]1O</smiles><smiles>COCO[C@H]1[C@H](Oc2cc(O)c3c(c2)OCCC3=O)O[C@H](CO)[C@@H](O)[C@H]1O</smiles><smiles>[R]Oc1ccccc1Br</smiles><smiles>COc1cc2oc(-c3ccc(O)cc3)cc(=O)c2c(O)c1C1O[C@H](CO)[C@@H](O[C@@H]2O[C@H](CO)[C@@H](O)[C@H](O)[C@H]2O)[C@H](O)[C@H]1O</smiles>

(67) Hesperidin: $\mathrm{R}_{1}=\mathrm{OH}, \mathrm{R}_{2}=\mathrm{CH}_{3}$

(69) Zivulgarin

(68) Naringin: $R_{1}=H, R_{2}=H$<smiles>[R3]c1cc(-c2oc3cc(O)cc(O)c3c(=O)c2[R])ccc1O</smiles>

(70) Apigenin: $\mathrm{R}_{1}=\mathrm{H}, \mathrm{R}_{2}=\mathrm{H}$

(71) Quercetin: $\mathrm{R}_{1}=\mathrm{CH}_{3}, \mathrm{R}_{2}=\mathrm{CH}_{3}$

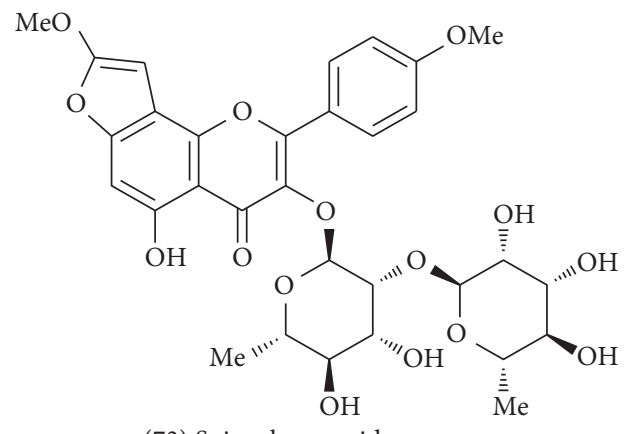

(73) Spinorhamnoside<smiles>O=c1cc(-c2ccc(O)cc2)oc2c([C@@H]3O[C@H](CO)[C@@H](O)[C@H](O)[C@H]3O)c(O)c([C@@H]3O[C@H](CO)[C@@H](O)[C@H](O)[C@H]3O)c(O)c12</smiles>

(72) Vicenin-2

$\mathrm{OH}$<smiles>O=c1cc(-c2ccc(O)cc2)oc2c([C@@H]3O[C@H](CO)[C@@H](O)[C@H](O)[C@H]3O)c(O)ccc12</smiles>

(75) Puerarin<smiles>O=c1cc(-c2ccc(O[C@@H]3O[C@H](CO)[C@@H](O)[C@H](O)[C@H]3O)cc2)oc2c(O[C@@H]3O[C@H](CO)[C@@H](O)[C@H](O)[C@H]3O)c(O)cc(O)c12</smiles>

(74) Glucosyl-vitexin<smiles>O=c1cc(-c2ccc(O)cc2)oc2cc(O)c([C@@H]3O[C@H](CO)[C@@H](O)[C@H](O)[C@H]3O)c(O)c12</smiles>

(76) Isovitexin<smiles>O=c1c(-c2ccccc2)coc2ccccc12</smiles>

(77) Isoflavone

Figure 5: Continued. 


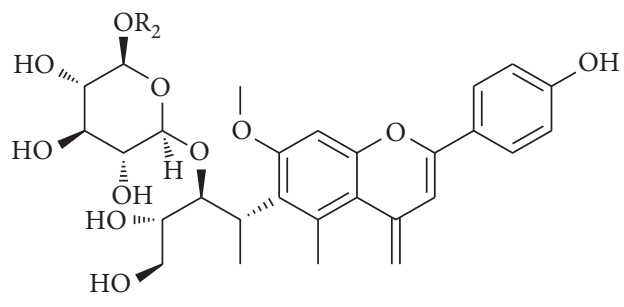

(78) 6"' -Vanilloylspinosin: $\mathrm{R}_{1}=\mathrm{H}, \mathrm{R}_{2}=$ vanilloy

(79) 6", 6"' -Diferuloylspinosin: $\mathrm{R}_{1}$ = feruloyl, $\mathrm{R}_{2}=$ feruloyl

(80) 6" - $O$-feruloylspinosin: $\mathrm{R}_{1}=$ feruloyl, $\mathrm{R}_{2}=\mathrm{H}$

(81) $6^{\prime \prime \prime}-O$-feruloyl-6"' - $p$-hydroxybenzoylspinosin: $\mathrm{R}_{1}=$ feruloyl, $\mathrm{R}_{2}=\mathrm{A}$

(82) $6^{\prime \prime \prime}-O$ - (3S-1-N- $\beta$-D-glucopyranosyl-2-oxo-3-hydroxy-indole-3-acetyl)spinosin: $\mathrm{R}_{1}=\mathrm{H}, \mathrm{R}_{2}=\mathrm{B}\left(3^{\prime \prime \prime \prime}-S\right)$

(83) $6^{\prime \prime \prime}-O$ - (3R-1-N- $\beta$-D-glucopyranosyl-2-oxo-3-hydroxy-indole-3-acetyl)spinosin: $\mathrm{R}_{1}=\mathrm{H}, \mathrm{R}_{2}=\mathrm{B}\left(3^{\prime \prime \prime \prime}-R\right)$

(84) $6^{\prime \prime}-O-\left(3 S-1-N-\beta\right.$ - $D$-glucopyranosyl-2-oxo-3-hydroxy-indole-3-acetyl)spinosin: $\mathrm{R}_{1}=\mathrm{B}\left(3^{\prime \prime \prime \prime}-S\right), \mathrm{R}_{2}=\mathrm{H}$

(85) $6^{\prime \prime}-O-\left(3 R-1-N-\beta\right.$ - D-glucopyranosyl-2-oxo-3-hydroxy-indole-3-acetyl)spinosin: $\mathrm{R}_{1}=\mathrm{B}\left(3^{\prime \prime \prime \prime}-R\right), \mathrm{R}_{2}=\mathrm{H}$

(86) $6^{\prime \prime}$-O- (3S-1-N- $\beta$-D-glucopyranosyl-2-oxo-3-hydroxy-indole-3-acetyl)-6"' -feruloylspinosin: $\mathrm{R}_{1}=\mathrm{B}\left(3^{\prime \prime \prime \prime}-S\right), \mathrm{R}_{2}=$ feruloyl

(87) $6^{\prime \prime}$ - $O$ - (3R-1-N- $\beta$-D-glucopyranosyl-2-oxo-3-hydroxy-indole-3-acetyl)-6"'-feruloylspinosin: $\mathrm{R}_{1}=\mathrm{B}\left(3^{\prime \prime \prime \prime}-R\right), \mathrm{R}_{2}=$ feruloyl

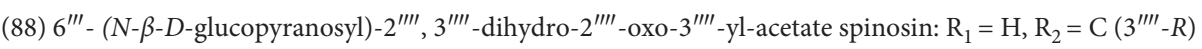

(89) epi-6"' - (N- $\beta$-D-glucopyranosyl)-2 $2^{\prime \prime \prime \prime}, 3^{\prime \prime \prime}-$ dihydro- $2^{\prime \prime \prime \prime}$-oxo- $3^{\prime \prime \prime \prime}$-yl-acetate spinosin: $\mathrm{R}_{1}=\mathrm{H}, \mathrm{R}_{2}=\mathrm{C}\left(3^{\prime \prime \prime \prime}-S\right)$

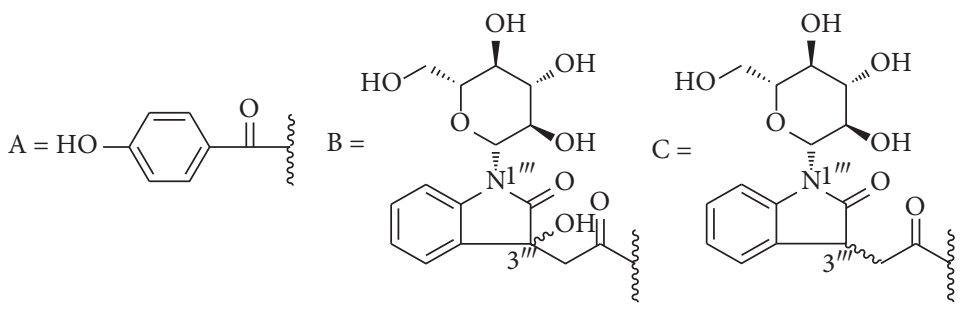

FIGURE 5: Chemical structures of flavonoids in ZS.

4.4. Fatty Acids and Volatile Oils (90-118). ZS oil is stable on oxidation and has oil content as high as $31.8 \%$ and total vitamin E content of $0.1867 \mathrm{mg} / \mathrm{g}$ [20]. In 2006, Wang et al. extracted ZS by Soxhlet extraction to determine fatty acids. The fatty acids in the oil were esterified by sodium hydroxide-methanol and then analyzed by gas chromatography-mass spectrometry (GC/MS). They separated and identified 17 different types of fatty acids from ZS, accounting for $95.33 \%$ of the total fatty acids. Unsaturated fatty acids account for $80.20 \%$ and saturated fatty acids account for $15.13 \%$ of the total fatty acids [21]. In addition, ZS contain about 32\% fat oil. Che et al. extracted 21 different types of fatty oils from ZS using supercritical $\mathrm{CO}_{2}$ extraction [22]. In 2001, Chen et al. first applied supercritical fluid extraction technology to extract fat oil from ZS and as a result identified 12 fatty acids [20]. Lu et al. showed that ZS oil is mainly composed of six fatty acids, among which oleic acid, linoleic acid, and linolenic acid had the highest contents of $49.1 \%$, 26.0\%, and 4.1\%, respectively. In addition, the oil of ZS contains a small amount of lauric acid, palmitoleic acid, and docosahexanoic acid [23]. A summary of the fatty acids and volatile oils found in ZS is shown in Figure 6.

4.5. Polysaccharides. ZS polysaccharide is a kind of polysaccharide extracted from ZS. Previous studies have shown that ZS polysaccharide had obvious anti-inflammatory and immuneregulating biological activities [24, 25]. In 2008, Lin et al. showed that the optimal conditions for perfect yield (1.05\%) of polysaccharide extracted from ZS with ultrasound assisted extraction method were extraction temperature $52.5^{\circ} \mathrm{C}$, extraction time $21.2 \mathrm{~min}$, extraction power $134.9 \mathrm{~W}$, and ratio of liquid to solid $26.3 \mathrm{~mL} / \mathrm{g}$. HPLC-ELSD method determined that ZS polysaccharide mainly contains two kinds of polysaccharides with molecular weights of $10000 \mathrm{kDa}$ and $2.34 \mathrm{kDa}$, respectively. In addition, the purified polysaccharide contains glucuronic acid (0.89\%), mannose (15.42 $\pm 0.08 \%)$, rhamnose $(18.36 \%)$, glucose $(0.20 \%)$, galactose $(35.49 \%)$, and xylose $(29.33 \%)$ (Figure 7) [26]. In the same year, they also found that ZS polysaccharide decolorization parameters with D101 macroporous adsorption resin $(2 \mathrm{mg} / \mathrm{mL}$ for the sample concentration, $3.5 \mathrm{~mL}$ for the volume, and $4 \mathrm{BV} / \mathrm{h}$ for the elution flow rate) is the best decoloration method. Under the condition, the values of polysaccharide decolorization rate and retention rate were $61.32 \%$ and $87.05 \%$, respectively [27].

4.6. Other Constituents (119-151). ZS also has various trace elements and eight amino acids that are essential to humans [17, 28]. Non ribosomal peptides [29], ferulic acid (No. 138), phytosterols (No. 139) [30] and vitamin C (No. 134) have also been found. In addition, some other compounds of ZS have been identified [31]. A summary of the other chemical compounds found in ZS is shown in Figure 8. 
<smiles>CC(C)CCCCCC(=O)O</smiles>

(90) 12-Methyl-tridecanoic acid: $\mathrm{n}=9$

(91) 14-Methyl-pentadecanoic acid: $\mathrm{n}=11$

(92) 15-Methyl-hexadecanoic acid: $\mathrm{n}=12$<smiles>CCCCC(C)C(=O)O</smiles>

(95) Tetradecanoic acid: $\mathrm{n}=11$

(96) Pentadecanoic acid: $\mathrm{n}=12$

(97) Hexadecanoic acid: $\mathrm{n}=13$

(98) Octadecanoic acid: $\mathrm{n}=15$

(99) Heneicosanoic acid: $n=18$

(100) Docosanoic acid: $\mathrm{n}=19$

(101) Tricosanoic acid: $\mathrm{n}=20$

(102) Lauric acid: $\mathrm{n}=9$

(103) Myristic acid: $\mathrm{n}=11$

(104) Pentadecanoic acid: $\mathrm{n}=12$

(105) Palmitic acid: $\mathrm{n}=13$

(106) Stearic acid: $\mathrm{n}=15$

(107) Arachidic Acid: $\mathrm{n}=17$

(108) Behenic acid: $\mathrm{n}=19$

(109) Lignoceric acid: $\mathrm{n}=21$

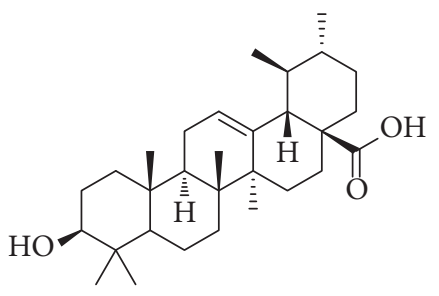

(116) Ursolic acid<smiles>CCCCCCCCCCC(=O)O</smiles>

(93) Gaidic acid: $\mathrm{n}=12$

(94) Eicosenoic acid: $n=16$<smiles>[R]C=CCC(=O)O</smiles>

(110) 9-Hexadecenoic acid: $\mathrm{n}=7, \mathrm{R}=$

(111) 9, 12-Octadecadienoic acid: $\mathrm{n}=7, \mathrm{R}=$

(112) 9, 12, 15-Octadecatrienoic acid: $\mathrm{n}=7, \mathrm{R}=$

(113) 12, 15-Octadecadienoic acid: $\mathrm{n}=10, \mathrm{R}=$

(114) Linoleic acid: $\mathrm{n}=7, \mathrm{R}=$

(115) 11-Eicosenoic acid: $\mathrm{n}=9, \mathrm{R}=$

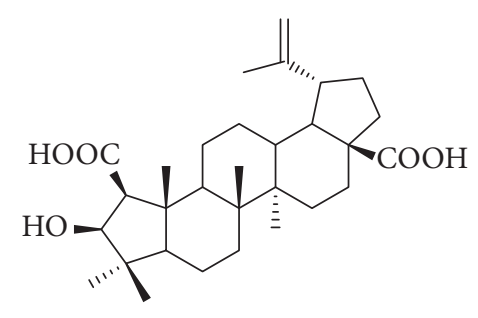

(117) Epiceanothic acid<smiles>CC1(C)CC[C@]2(C(=O)O)CC[C@H]3C(=CC[C@H]4[C@@]3(C)CC[C@H]3C(C)(C)[C@@H](O)CC[C@]43C)[C@H]2C1</smiles>

(118) Oleanolic acid

FIgURE 6: Chemical structures of fatty acid and volatile in ZS.<smiles>CC1(C)O[C@@H]2O[C@@H]3C(O)C(=O)O[C@@H]3[C@H]2O1</smiles>

Glucuronic acid<smiles>C[N+]([O-])(O)[C@@H]1[C@H](O)[C@@H](CO)O[C@H](O)[C@@H]1O</smiles>

Mannose<smiles>C[C@@H]1[C@H](O)C(O)O[C@H](CO)[C@@H]1O</smiles>

Galactose<smiles>C[C@@H]1OC(O)[C@H](O)[C@H](O)[C@@H]1O</smiles><smiles>O=C[C@H](O)[C@@H](O)[C@@H](O)CO</smiles>

FIGURE 7: Monosaccharides included in the purified ZS polysaccharide.

\section{Pharmacology}

ZS-derived extracts are pharmacologically active and exert many effects, including that on the central nervous system and the cardiovascular system. The main pharmacological effects of ZS include sedation and hypnosis, ameliorating effect of learning and memory, anti-inflammation, antioxidation, anticonvulsion, blood pressure lowering, lipid lowering, antiplatelet aggregation, enhancement of immune function, antihypoxia, antimyocardial ischemia, 
<smiles>[R]C(N)C(=O)O</smiles>

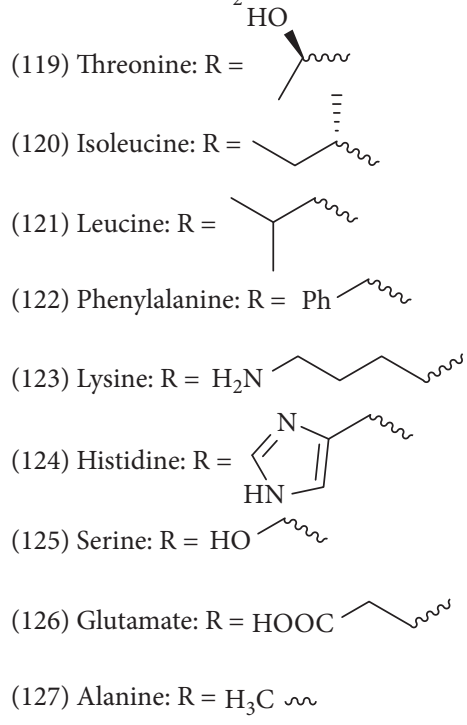

(128) L (+)-Cysteine: R = HS<smiles>CCc1ccc(O)cc1</smiles>

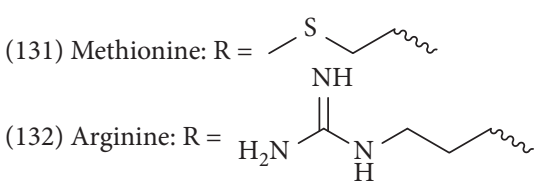<smiles>CC(C)(C)OC(=O)N[C@@H](Cc1ccc(O)cc1)C(=O)O</smiles>

(133) Boc-D-Tyr-OH<smiles>O=C1O[C@H]([C@@H](O)CO)C(O)=C1O</smiles>

(134) Vitamin C

(135) Proline<smiles>NCC(=O)O</smiles>

(136) Glycine<smiles>OCC(O)CO</smiles>

(137) Glycerol<smiles>COc1cc(/C=C/C(=O)O)ccc1O</smiles>

(138) Ferulic acid<smiles>CC[C@H](CC[C@@H](C)[C@H]1CCC2[C@@H]3CC=C4C[C@@H](O)CC[C@H]4[C@H]3CC[C@]21C)C(C)C</smiles>

(139) Phytosterols<smiles></smiles>

(140) Amphibine D
(141) Fe, $142 \mathrm{Mn}, 143 \mathrm{Zn}$,

(144) $\mathrm{Cu}, 145 \mathrm{~K}, 146 \mathrm{Ca}$,

(147) Na, $148 \mathrm{Se}, 149 \mathrm{Mo}$,

(150) $\mathrm{Ni}, 151 \mathrm{Cr}$

FIGURE 8: Other chemical structures in ZS.

antiarrhythmia, and antiaging. In this section, the different pharmacological activities of ZS have been introduced and analyzed. A summary of pharmacological effects of ZS is shown in Table 1.
5.1. Effect on the Central Nervous System. Wang et al. studied the effects of ZS flavonoids $(0.1 \mathrm{~g} / \mathrm{kg})$ on improving the learning and memory ability in memory-impaired mice by using dark-avoidance test and maze test. The data showed 
that flavonoids could prolong the latent period of mice, reduce the erroneous times, and shorten the time of electric shock [32]. In the same year, it was also shown that intraperitoneal injection of ZS decoction $(5.0 \mathrm{~g} / \mathrm{kg})$ prolonged the pain threshold in mice [38]. Lee et al. showed that ZS ethanolic extract $(100 \mathrm{mg} / \mathrm{kg})$ could significantly ameliorate the scopolamine-induced cognitive impairment in mice [33]. Zhang et al. reported that the water extract of ZS played a necessary role in ameliorating memory retrieval disorders of mice induced by alcohol and improving the learning capacity to some extent [34]. Hou et al. and Wu et al. also got the above results, respectively $[35,36]$. Zhu et al. considered ZS jujubosides improved the cognition and memory of Alzheimer's disease rats. The mechanism may be through increase concentration of 5-serotonin content (5-HT), melatonin (MT), melatonin receptor (MTR), and delayed Tau protein hyperphosphorylation [37].

When You et al. compared the sedative and hypnotic effects of Os Draconis and ZS decoction $(6.25 \mathrm{~g} / \mathrm{kg})$, they concluded that ZS could inhibit the spontaneous activity, enhance the rate of falling asleep induced by sodium pentobarbital (in subthreshold dose), prolong the sleep time induced by sodium pentobarbital (in suprathreshold dose), and resist convulsion of mice [39]. Later, ZS was also shown to have an anticonvulsive effect in strychnine nitrate-treated mice [40]. Zhao et al. found that the total alkaloids $(50 \mathrm{mg} / \mathrm{kg})$ and cyclopeptide alkaloid $(20 \mathrm{mg} / \mathrm{kg}$ ) from ZS could markedly extend the latent period and dying time of convulsions episode in convulsive mice caused by strychnine [41]. It was noted that jujuboside A $(0.05-0.10 \mathrm{~g} / \mathrm{L})$ could inhibit the excitatory discharge effect caused by sodium penicillin (in vitro) [42]. In 2003, Zhang et al. showed that jujuboside A $(0.1 \mathrm{~g} / \mathrm{L})$ could significantly inhibit the release of glutamate in the hippocampus induced by sodium penicillin sodium, and the jujuboside A (0.05-0.10 g/L) could significantly inhibit the glutamate-induced release of intracellular $\mathrm{Ca}^{2+}$. These results show that jujuboside A can inhibit glutamate-mediated signaling pathways in the hippocampus [43].

5.2. Effect on the Cardiovascular System. Zhang et al. first treated spontaneously hypertensive rats by gavage with ZS total saponins $(5 \mathrm{mg} / \mathrm{kg})$ and showed that they had a clear effect on reducing blood pressure [44]. Following this, Liu et al. conducted a similar experiment and observed a blood pressure lowering effect [45]. In addition, $\mathrm{Wu}$ et al. found that after orally treating quails with ZS oil $(2.5 \mathrm{~mL} / \mathrm{kg})$, the total cholesterol (TC), the low density lipoprotein (LDL), and the triglyceride (TG) levels decreased. On the contrary, the high density lipoprotein/the low density lipoprotein $(\mathrm{H} /$ L) increased [47]. Wu and Liu et al. also found a similar result in rats and rabbits, respectively [46, 48]. In 1985, Liu et al. first studied the antimyocardial ischemia effect of ZS ethanol extract by intraperitoneal administration $(4 \mathrm{~g} / \mathrm{kg})$ and intravenous administration $(1.5 \mathrm{~g} / \mathrm{kg})$. The data showed that the ethanol extract had a tendency to have an antimyocardial ischemia effect in rats injected with pituitrin
[51]. In addition, Zhang et al. and $\mathrm{Wu}$ showed that $\mathrm{ZS}$ total saponins $(0.3 \mathrm{~g} / \mathrm{kg}$ and $0.12 \mathrm{~g} / \mathrm{kg})$ could improve myocardial ischemia [49, 50]. Mechanistically, Huang demonstrated that pretreatment with jujuboside A $(20 \mathrm{mg} / \mathrm{mL})$ could upregulate $\mathrm{Bcl}-2$ and downregulate Bax protein expression levels, thereby increasing the Bcl-2/Bax ratio, inhibiting the release of cytochrome $\mathrm{C}$ from mitochondria, and decreasing the activity of caspase- 3 in myocardial tissue, thus reducing cardiomyocyte apoptosis [52].

Experiments in other studies have also shown that ZS has an antiarrhythmic effect. In one experiment, rats were given a sublingual intravenous injection of an ethanol extract of ZS solution $(2 \mathrm{~g} / \mathrm{kg})$, which was shown to inhibit the arrhythmia induced by aconitine and barium chloride [51]. Following this, $\mathrm{Xu}$ et al. comprehensively studied the preventive and therapeutic effects of a water extract of ZS on arrhythmia induced by aconitine, chloroform, and barium chloride in rats and mice; the results showed that the water extract of ZS could treat arrhythmia induced by aconitine and barium chloride in rats and prevent arrhythmia induced by chloroform anesthesia in mice [53]. Additionally, ZS decoction has been shown to improve tolerance to hypoxia [54]. Wu et al. and Zhang et al. studied the antiplatelet aggregation activity of ZS extract. Wu et al. gavaged Japanese male quails with ZS oil $(2.5 \mathrm{mg} / \mathrm{kg})$ and Zhang et al. studied the antiplatelet aggregation effect of total saponins $(25-660 \mathrm{mg} / \mathrm{L})$ in rabbits. A significant inhibition of platelet aggregation was observed in both Japanese male quails and rabbits, and this effect was closely related to thromboxane $\mathrm{B}_{2}\left(\mathrm{TXB}_{2}\right)$ [55].

5.3. Sedative and Hypnotic Effects. The sedative and hypnotic effects are the main pharmacological effects of ZS [62]. Wu et al. administered total saponins from ZS at $240 \mathrm{mg} / \mathrm{kg}$ to mice, which significantly reduced the spontaneous activity of the mice. At the $480 \mathrm{mg} / \mathrm{kg}$ dose, there was a significant increase in the number of mice who lost the reflex induced by a subthreshold dosage of sodium pentobarbital. The same result was obtained when total flavonoids were administered at a dose of $300 \mathrm{mg} / \mathrm{kg}$ [57]. You et al. concluded that ZS decoction (6.25 g/ $\mathrm{kg}$ ) could significantly reduce spontaneous activity, prolong the sleep time disrupted by a suprathreshold dose of sodium pentobarbital, and increase the sleep rate in mice disrupted by a subthreshold dose of sodium pentobarbital [39]. Jiang et al. also showed that both ZS flavonoids and saponins ( $40 \mathrm{mg} / \mathrm{kg}$ ) could significantly reduce the spontaneous activity of mice and increase the sleeping time of mice. However, ZS polysaccharides did not have the sedative and hypnotic effect [59]. In addition, it was reported that ZS alkaloids could prolong the sleeping time of mice induced by sodium pentobarbital [60]. Jia et al. reported that ZS oil had the same effect; Sun et al. and Li also reported that ZS water extract had the same effect [40, 61, 63].

In 2008, Li et al. studies the sedative and hypnotic effects of ZS oil $(1.8 \mathrm{~g} / \mathrm{kg})$, obtained by a pressing method and supercritical $\mathrm{CO}_{2}$ extraction, in mice. The results showed that both methods could reduce the spontaneous activity of mice, shorten the sleep latency of mice induced by a suprathreshold dose of sodium pentobarbital, and increase the sleep rate in mice induced with a subthreshold dose of 
TABle 1: Pharmacological effects of ZS.

\begin{tabular}{|c|c|c|c|c|c|}
\hline Pharmacological effects & Detail & Extracts/compounds & Results & $\begin{array}{c}\text { In } \\
\text { vitro/in } \\
\text { vivo }\end{array}$ & Ref. \\
\hline \multirow{12}{*}{$\begin{array}{l}\text { Effect on the central } \\
\text { nervous system }\end{array}$} & \multirow{7}{*}{ Improving dysmnesia } & Flavonoids & $\begin{array}{l}\text { Latent period } \uparrow \text {, erroneous times } \downarrow \text {, time } \\
\text { of electric shock } \downarrow\end{array}$ & In vivo & {$[32]$} \\
\hline & & & Passive avoidance task $\uparrow, \mathrm{Y}$-maze task $\uparrow$, & & \\
\hline & & Ethanolic extract & $\begin{array}{c}\text { Morris water maze task } \uparrow, \mathrm{ERK}-\mathrm{CREB}- \\
\mathrm{BDNF} \uparrow, \mathrm{NMDA} \uparrow\end{array}$ & In vivo & {$[33]$} \\
\hline & & Water extract & Passive avoidance task $\uparrow, \mathrm{Y}$-maze task $\uparrow$ & In vivo & {$[34]$} \\
\hline & & Decoction & $\begin{array}{c}\text { Step down test } \uparrow, \text { Morris water maze } \\
\operatorname{task} \uparrow\end{array}$ & In vivo & {$[35]$} \\
\hline & & ZS oil & $\begin{array}{l}\text { Passive avoidance task } \uparrow \text {, Morris water } \\
\text { maze task } \uparrow\end{array}$ & In vivo & {$[36]$} \\
\hline & & Jujubosides & 5-HT $\uparrow, \mathrm{MT} \uparrow, \mathrm{MTR} \uparrow$, Tau protein $\downarrow$ & In vivo & {$[37]$} \\
\hline & \multirow[t]{2}{*}{ Analgesic effects } & Water extract & Pain threshold $\uparrow$ & In vivo & {$[38]$} \\
\hline & & Decoction & $\begin{array}{c}\text { Spontaneous activity } \downarrow \text {; sleep time } \uparrow ; \\
\text { convulsion; } \downarrow\end{array}$ & In vivo & {$[39,40]$} \\
\hline & \multirow[t]{3}{*}{ Analgesic effects } & $\begin{array}{l}\text { Total alkaloids, } \\
\text { cyclopeptide and } \\
\text { alkaloid }\end{array}$ & $\begin{array}{c}\text { Latent period of convulsion } \uparrow \text {; dying } \\
\text { time } \uparrow\end{array}$ & In vivo & {$[41]$} \\
\hline & & Jujuboside A & $\begin{array}{c}\text { Hyperactivity of hippocampal CA1 } \\
\text { area } \downarrow\end{array}$ & In vitro & {$[42]$} \\
\hline & & Jujuboside A & $\begin{array}{l}\text { Release of glutamate and intracellular } \\
\qquad \mathrm{Ca}^{2+} \downarrow\end{array}$ & In vivo & {$[43]$} \\
\hline \multirow{12}{*}{$\begin{array}{l}\text { Effect on the } \\
\text { cardiovascular system }\end{array}$} & Antihypertensive effects & Total saponins & Tail artery blood pressure $\downarrow$ & In vivo & {$[44,45]$} \\
\hline & Antihyperlipoidemia & Total saponins & TC, LDL, TG $\downarrow ; \mathrm{H} / \mathrm{L} \uparrow$ & In vivo & {$[46]$} \\
\hline & effects & ZS oil & TC, LDL, TG $\downarrow ; \mathrm{H} / \mathrm{L} \uparrow$ & In vivo & {$[47,48]$} \\
\hline & \multirow{3}{*}{$\begin{array}{l}\text { Improving myocardial } \\
\text { ischemia }\end{array}$} & Total saponins & $\begin{array}{c}\text { Infarcted area } \downarrow \text {, } S \text {-T piece and T wave } \\
\text { value } \downarrow\end{array}$ & In vivo & {$[49]$} \\
\hline & & Total saponins & T wave value $\downarrow$ & In vivo & {$[50]$} \\
\hline & & Ethanol extract & Myocardial ischemic rats $\downarrow$ & In vivo & {$[51]$} \\
\hline & $\begin{array}{l}\text { Alleviating myocardial } \\
\text { reperfusion injure }\end{array}$ & Jujuboside A & $\begin{array}{c}\text { Bcl-2/Bax } \uparrow, \text { cytochrome } \mathrm{C} \downarrow \text {, caspase- } \\
3 \downarrow\end{array}$ & In vitro & {$[52]$} \\
\hline & \multirow[t]{2}{*}{ Antiarrhythmic effects } & Water extract & $\begin{array}{c}\text { Occurrence of Arrhythmic } \uparrow \text {, mouse } \\
\text { survival time } \uparrow \text {, ventricular fibrillation } \downarrow\end{array}$ & In vivo & {$[53]$} \\
\hline & & Ethanol extract & Recovered sinus rhythm time $\downarrow$ & In vivo & {$[51]$} \\
\hline & $\begin{array}{l}\text { Improving hypoxia } \\
\text { tolerance }\end{array}$ & Decoction & Oxygen consumption of brain tissue $\downarrow$ & In vivo & {$[54]$} \\
\hline & & Total saponins & Platelet aggregation $\downarrow$, TXB $2 \downarrow$ & In vitro & {$[55]$} \\
\hline & Antiplatelet aggregation & Methanol extract & $\begin{array}{l}\text { GABAA receptor subunits and } \\
\text { glutamic acid decarboxylase } \uparrow\end{array}$ & In vivo & {$[56]$} \\
\hline \multirow{10}{*}{$\begin{array}{l}\text { Sedative and hypnotic } \\
\text { effects }\end{array}$} & \multirow{10}{*}{ Prolonging the sleep time } & $\begin{array}{l}\text { Total saponins, total } \\
\text { flavonoids }\end{array}$ & Spontaneous activity $\downarrow$, sleeping rate $\uparrow$ & In vivo & {$[57]$} \\
\hline & & ZS oil & $\begin{array}{l}\text { Spontaneous activity } \downarrow \text {, sleeping time } \uparrow \text {, } \\
\text { sleeping number } \uparrow \text {, sleeping latency }\end{array}$ & In vivo & {$[58]$} \\
\hline & & $\begin{array}{l}\text { Flavonoids and } \\
\text { saponins }\end{array}$ & Spontaneous activity $\downarrow$, sleeping time $\uparrow$ & In vivo & [59] \\
\hline & & Alkaloids & Sleeping time $\uparrow$ & In vivo & {$[60]$} \\
\hline & & Decoction & $\begin{array}{c}\text { Spontaneous activity } \downarrow \text {, sleep time } \uparrow \text {, } \\
\text { convulsion; } \downarrow\end{array}$ & In vivo & [39] \\
\hline & & ZS oil & Sleeping rate $\uparrow$, sleeping time $\uparrow$ & In vivo & {$[61]$} \\
\hline & & Water extract & Sleeping time $\uparrow$ & In vivo & {$[62]$} \\
\hline & & Total extract & Spontaneous activity $\downarrow$, sleeping time $\uparrow$ & In vivo & {$[63]$} \\
\hline & & Jujuboside A & $\begin{array}{c}\text { Total time of sleep during the day and } \\
\text { night } \uparrow\end{array}$ & In vitro & {$[64]$} \\
\hline & & Water extract & Activity times $\downarrow$, stand-up times $\downarrow$ & In vivo & {$[38]$} \\
\hline
\end{tabular}


TABLE 1: Continued.

\begin{tabular}{|c|c|c|c|c|c|}
\hline Pharmacological effects & Detail & Extracts/compounds & Results & $\begin{array}{l}\text { In } \\
\text { vitro/in } \\
\text { vivo }\end{array}$ & Ref. \\
\hline \multirow{8}{*}{$\begin{array}{l}\text { Antianxiety and } \\
\text { antidepressant effects }\end{array}$} & \multirow{4}{*}{ Antianxiety effects } & Decoction & c-Fos protein $\downarrow$ & In vivo & {$[65]$} \\
\hline & & Decoction & $\begin{array}{c}\text { Food and water intake } \downarrow \text {, weight } \uparrow, T 3 \downarrow \text {, } \\
\text { T4 } \downarrow \downarrow, \text { TSH } \uparrow\end{array}$ & In vivo & {$[66]$} \\
\hline & & Alcohol extract & $\begin{array}{c}\text { GABA } \uparrow, \text { GABAAR } 1 \uparrow, \text { Glu } \downarrow \\
\text { NMDAR } 1 \downarrow\end{array}$ & In vivo & [67] \\
\hline & & Alcohol extract & Sleeping time $\uparrow$, locomotor activity $\downarrow$ & In vivo & {$[68]$} \\
\hline & \multirow{4}{*}{ Antidepressant effects } & $\begin{array}{l}\text { Decoction, } \\
\text { polysaccharide, } \\
\text { alkaloid }\end{array}$ & Immobility time $\downarrow, \operatorname{SOD} \uparrow, \mathrm{MDA} \downarrow$ & In vivo & {$[69]$} \\
\hline & & Total flavonoids & Immobility time $\downarrow$ & In vivo & {$[70]$} \\
\hline & & Total saponins & Immobility time $\downarrow$ & In vivo & {$[71]$} \\
\hline & & Total alkaloids & Immobility time $\downarrow$ & In vivo & {$[72]$} \\
\hline \multirow{3}{*}{$\begin{array}{l}\text { Anti-inflammatory and } \\
\text { antioxidant effects }\end{array}$} & Anti-inflammatory effects & Water extract & $\begin{array}{c}\text { Capillary permeability } \downarrow \text {, foot } \\
\text { swelling } \downarrow \text {, granulation tissue } \\
\text { proliferation } \downarrow\end{array}$ & In vivo & {$[73]$} \\
\hline & \multirow[b]{2}{*}{ Antioxidant effects } & ZS oil & $\begin{array}{c}\text { TAC } \uparrow, \mathrm{O}_{2} \bullet-\uparrow, \bullet \mathrm{OH} \uparrow, \mathrm{DDPH} \uparrow, \mathrm{ALP} \uparrow, \\
\mathrm{MDA} \downarrow, \mathrm{GSH}-\mathrm{Px} \uparrow\end{array}$ & In vitro & {$[64]$} \\
\hline & & Total flavonoids & $\begin{array}{c}\text { Scavenging ability for DPPH and } \\
\text { ABTS + radicals } \uparrow, \text { reduce potassium } \\
\text { ferricyanide } \uparrow\end{array}$ & In vitro & {$[74]$} \\
\hline \multirow{6}{*}{$\begin{array}{l}\text { Other pharmacological } \\
\text { effects }\end{array}$} & \multirow{2}{*}{$\begin{array}{l}\text { Immunomodulatory } \\
\text { activity }\end{array}$} & $\begin{array}{l}\text { Ethanol extract } \\
\text { Ethanol extract }\end{array}$ & $\begin{array}{l}\text { Appetite } \uparrow \text {, body weight } \uparrow, \mathrm{IF} \uparrow, \mathrm{DH} \downarrow \\
\text { Interferon-gamma } \uparrow \text {, interleukin- } 4 \uparrow\end{array}$ & $\begin{array}{l}\text { In vivo } \\
\text { In vivo }\end{array}$ & $\begin{array}{l}{[75]} \\
{[76]}\end{array}$ \\
\hline & & Polysaccharide & $\begin{array}{c}\mathrm{NO} \uparrow, \mathrm{COX}-2 \uparrow, \mathrm{iNOS} \uparrow, \mathrm{p}-\mathrm{I} \kappa \mathrm{B}-\alpha \uparrow, \mathrm{p}- \\
\mathrm{ERK} \uparrow\end{array}$ & In vitro & {$[77]$} \\
\hline & $\begin{array}{l}\text { Preventing and treating of } \\
\text { cancer }\end{array}$ & ZS oil & Body weight $\downarrow$, survival time $\uparrow$ & In vivo & {$[78]$} \\
\hline & Antiaging effects & Decoction & SOD $\uparrow$ & In vivo & [79] \\
\hline & Protecting kidney & Flavonoid suspension & HepG2 $\downarrow$ & In vitro & {$[80,81]$} \\
\hline & Neuroprotective effects & $6^{\prime \prime \prime}$-Feruloylspinosin & ROS $\downarrow$, p $62 \downarrow$, pink $1 /$ parkin $\uparrow$ & In vitro & {$[82]$} \\
\hline
\end{tabular}

sodium pentobarbital [58]. It has also been found that jujuboside A $(0.25 \mathrm{mg} / \mathrm{mL})$ could significantly prolong the average sleeping time of Drosophila during both the day and night. The dosage of $1 \mathrm{mg} / \mathrm{mL}$ was the best concentration and 3 days was the best time for administration [64]. In addition, a mechanistic study by $\mathrm{Hu}$ et al. on daytime rapid eye movement in vitro and in vivo with a methanol extract of ZS showed that the inhibition of neuronal excitation was related to the activation of the $\gamma$-aminobutyric acid (GABA) system [56]. It was also found that ZS water decoction had sedative and analgesic effects [38].

5.4. Antianxiety and Antidepressant Effects. In 2018, Hua gavaged ZS decoction $(17.5 \mathrm{~g} / \mathrm{kg})$ to rats with anxiety and found that the expression of the c-Fos protein in the basolateral amygdale (BLA) neurons and the discharge frequency of the action potential in neurons were decreased [65]. In 2014, Guo found that the intragastric administration of ZS decoction $(10 \mathrm{~g} / \mathrm{kg})$ could reduce the abnormal increase in food intake and water intake within 24 hours in rats with Yin deficiency heat syndrome; increase body weight, reduce the kidney and the adrenal function, significantly reducing triiodothyronine (T3) and thyroxine (T4) levels, increasing thyroid-stimulating hormone (TSH) levels; and increase the percentage of open-arm entry times, open-arm retention times, and the number passages through open and dark boxes during combined elevated cross maze and light box tests. From the above findings, it is clear that that ZS has an obvious antianxiety effect in rats with Yin deficiency heat syndrome [66]. Rong et al. have also shown that the antianxiety mechanism of ZS alcohol extract $(0.055 \mathrm{~g} / \mathrm{kg})$ may be related to an increase in GABA levels in the central nervous system, an increase in $\mathrm{GABAAR}_{1}$ expression levels, a decrease in Glu content, and a decrease in $\mathrm{NMDAR}_{1}$ expression levels [67]. In addition, another study suggested that the ethanolic extract $(0.5 \mathrm{~g} / \mathrm{kg})$ possessed anxiolytic effect, and it also possessed sedative effect at higher dose $(2.0 \mathrm{~g} / \mathrm{kg})$ [68].

The antidepressant effects of ZS have also been studied. Zhang et al. compared the effects of a water decoction and ZS polysaccharides and alkaloids $(2.0 \mathrm{~g} / \mathrm{kg})$ on depression in mice. The data showed that the water decoction had the best effect followed by that of the alkaloids and polysaccharides [69]. In 2011, Zhao et al. studied the effects of total flavonoids $(50,100$, and $200 \mathrm{mg} / \mathrm{kg}$ ) in a behavioral despair depression model in mice. In all three treatment groups, there was a reduction in forced swimming and tail suspension immobility times [70]. Zhao et al. performed a similar experiment in the same year [71]. Zhu et al. investigated the antidepressant activity of ZS total alkaloids (5, 10, and $20 \mathrm{mg} / \mathrm{kg}$ ) using depression models such as the 
reserpine-induced hypothermia test, tail suspension stress test, and open field test. The results showed that alkaloids could shorten the immobility time of tail suspension in mice, and there was a dose-dependent relationship among the three dosage groups. There was an effective antagonism of hypothermia in the mice. The open field experiment showed that there was no significant difference between the three groups in autonomous activity; thus, it was concluded that the antidepressant effect was not caused by an enhancement of autonomous activity [72].

5.5. Anti-Inflammatory and Antioxidative Effects. Bao et al. studied the effects of ZS water extract $(1 \mathrm{~g} / 100 \mathrm{~g})$ on capillary permeability (abdominal cavity, back, and auricle) by intragastric administration in mice and on egg-white-induced foot swelling and granulation tissue proliferation in rats. The results showed that the ZS water extract could inhibit capillary permeability in the abdominal cavity, the back skin, and the auricle of mice. The anti-inflammatory effects of the extract on egg-white albumin-induced swelling in the hind feet and granuloma induction caused by implantation of paper under the axilla of rats were similar to those of prednisone [73].

Zhang et al. assessed the in vitro total antioxidant (TA) capacity, superoxide radical scavenging capacity $\left(\mathrm{O}_{2} \bullet{ }^{-}\right)$, hydroxyl radical scavenging capacity $(\bullet \mathrm{OH}), \mathrm{DDPH}$ radical scavenging capacity, and antilipid peroxidation of ZS oil. The results showed that the scavenging ability of ZS oil toward hydroxyl radicals was lower than that of vitamin $\mathrm{E}$ (VE), whereas the total antioxidant capacity was equal to that of VE. In contrast, the DPPH radical scavenging ability, superoxide anion radical scavenging ability, and the antilipid peroxidation (ALP) effect were all better than those of VE. Experiments in vivo also showed that ZS oil could significantly reduce the malondialdehyde (MDA) content in the blood and liver of a D-galactose oxidation model in mice and significantly increase glutathione peroxidase (GSH-Px) activity [83]. Zhao et al. also found that total flavonoids $(0.05 \mathrm{mg} / \mathrm{mL})$ had an obvious scavenging ability for DPPH and ABTS + radicals (IC50 values of $0.70 \mathrm{mg} / \mathrm{mL}$ and $0.15 \mathrm{mg} / \mathrm{mL}$, respectively), as well as an ability to reduce potassium ferricyanide [74]. However, these chemical antioxidant assays like the DPPH assay are only simple and useful chemical assays; the therapeutic benefits of ZS were worth further studying. In 2018, Lin et al. reported ZS polysaccharides $(5 \mu \mathrm{g} / \mathrm{mL})$ could significantly promote the proliferation of RAW264.7 cells. Western blot test showed that ZS polysaccharides could significantly promote the release of $\mathrm{NO}$ and the expression of stress response protein (COX-2 and iNOS) in RAW264.7 cells. In addition, ZS polysaccharides could significantly promote the phosphorylation of $\mathrm{I} \kappa \mathrm{B}-\alpha$ and ERK protein, which also indicated that the polysaccharide has a certain immunomodulatory effect [77].

5.6. Other Pharmacological Effects. In addition to the pharmacological effects described above, ZS has other pharmacological effects. A study showed that oral ZS alcohol extract $(5 \mathrm{~g} / \mathrm{kg})$ increased the appetite and weight of mice, enhanced the cellular and humoral immune functions (IF), and antagonized the inhibition of delayed hypersensitivity (DH) induced by cyclophosphamide in mice. All these indicate that ZS alcohol extract had an immunopotentiating effect [75]. In 2010, Mishra and Bhatia also indicated that ZS aqueous-ethanolic extract $(100-400 \mathrm{mg} / \mathrm{kg})$ had the immunomodulatory potential [76]. Wang et al. examined the effect of ZS oil on body weight and survival time of mice with Ehrlich's ascites carcinoma (In vivo). The study proved that ZS oil $(0.35 \mathrm{~mL} / \mathrm{kg})$ could significantly prolong the survival in mice with cancer and inhibit body weight increases in mice with cancer in later life; it indicated that ZS had obvious antitumor effect on Ehrlich's ascites carcinoma [78]. A separate study showed that ZS water decoction $(20 \mathrm{ml} / \mathrm{kg})$ had a protective effect on the decrease in superoxide dismutase (SOD) in febrile mice induced by endotoxin [79]. In addition, Huang's team found that extracts $(100 \mathrm{mug} / \mathrm{mL})$ inhibited the growth of human hepatocellular carcinoma cells (HepG2) [80, 81]. In 2020, Yang et al. indicated that the $6^{\prime \prime \prime}$-feruloylspinosin of ZS $(50 \mu \mathrm{g} / \mathrm{mL})$ has neuroprotective effects. It could reduce beta-amyloid-induced cytotoxicity, lead to increasing a lifespan, and alleviate the oxidative stress. Furthermore, the functions are closely related to the promotion of autophagic activity [82].

In summary, ZS has a wide range of pharmacological activities, which include effects on the central nervous and cardiovascular systems. The main pharmacological effects of ZS are sedation and hypnosis, anti-inflammation, antioxidation, anticonvulsion, blood pressure and lipid lowering, antiplatelet aggregation, enhancing immune function, antihypoxia, antimyocardial ischemia, antiarrhythmia, and antiaging. These findings show that this plant can be used to treat many diseases. Although there are many pharmacological studies using ZS extracts and some of the main components of ZS have been identified, many of their mechanisms are unclear. Therefore, the pharmacological mechanism of action should be further studied.

\section{Pharmacokinetics}

Currently, little research has been performed to assess the pharmacokinetics of extracts and compounds derived from ZS. Liu et al. used LC-MS/MS method to study the pharmacokinetics of jujuboside A (oral administration, $30 \mathrm{mg} /$ $\mathrm{kg}$ ) in rats and successfully obtained the main pharmacokinetics: $\quad \mathrm{Kel}=0.1022 \pm 0.023 \mathrm{~h}^{-1}, \quad t_{(1 / 2 \beta)}=6.7 \pm 0.9 \mathrm{~h}$, $\mathrm{AUC}_{0 \longrightarrow 36}=1989.6 \pm 421.7 \mathrm{~h} \cdot \mathrm{ng}^{-1} \cdot \mathrm{mL}^{-1}, \quad \mathrm{AUC}_{0 \longrightarrow \infty}=$ $2159.1 \pm 401.4 \mathrm{~h} \cdot \mathrm{ng}^{-1} \cdot \mathrm{mL}^{-1}, \quad \mathrm{Vd}=131.3 \pm 38.6 \mathrm{~L}, \quad \mathrm{Cl}_{\text {tot }}=$ $13.95 \pm 2.47 \mathrm{~h} \cdot \mathrm{ng}^{-1} \cdot \mathrm{mL}^{-1}, \quad T_{\max }=2.0 \pm 0.0 \mathrm{~h}, C_{\max }=252.4 \pm$ $39.7 \mu \mathrm{g} \cdot \mathrm{L}^{-1}$ [84]. Zhang et al. used HPLC-MS/MS method to detect the concentration of jujuboside $\mathrm{A}$ in rat plasma and study the pharmacokinetics. The pharmacokinetic data was as follows: $\mathrm{Ke}=0.28 \mathrm{~h}, t_{1 / 2}=2.55 \mathrm{~h}, \mathrm{AUC}_{0 \longrightarrow t}=\mathrm{h} \cdot \mathrm{ng}^{-1} \cdot \mathrm{mL}^{-1}$, $\mathrm{AUC}_{0 \longrightarrow \infty}=3201.51 \mathrm{~h} \cdot \mathrm{ng}^{-1} \cdot \mathrm{mL}^{-1}$ in rat with intravenous administration and $\mathrm{Ke}=0.51 \mathrm{~h}, t_{1 / 2}=1.35 \mathrm{~h}, \mathrm{AUC}_{0 \longrightarrow t}=$ $206.02 \mathrm{~h} \cdot \mathrm{ng}^{-1} \cdot \mathrm{mL}^{-1}, \mathrm{AUC}_{0} \longrightarrow \infty=211.13 \mathrm{~h} \cdot \mathrm{ng}^{-1} \cdot \mathrm{mL}^{-1}$ in rat with oral administration [85]. Wang and Zheng et al. carried out two similar experiments and obtained the same results, 
respectively [86, 87]. Guo studied the distribution of spinosin, jujuboside $\mathrm{A}$, and jujuboside $\mathrm{B}$ in rats after the intragastric administration of a water decoction. These components could be detected in rats within $10 \mathrm{~min}$ and were detectable for up to $240 \mathrm{~min}$. The average distribution concentration and the $\mathrm{AUC}_{0-t}$ of spinosin were the largest in the small intestine, those of jujuboside A were the largest in the lung, and those of jujuboside $B$ were the largest in the large intestine [66]. In 2015, Gao et al. studied the pharmacokinetic effect of different combined administration with ZS and its main components in rats. The results showed that the maximum plasma concentration $\left(C_{\max }\right)$ and area under curve $\left(\mathrm{AUC}_{0-t}\right)$ of spinosin and ferulic acid in ZSFructus Schisandrae Chinensis and ZS-Salviae miltiorrhizae Radix groups were decreased, and the clearance rate (CL/F) was increased compared with the ZS group. However, the Zaoren Anshen prescription group showed higher $C_{\max }$ and $\mathrm{AUC}_{0-t}$ for spinosin and ferulic acid, but lower CL/F. Therefore, compared with ZS group, the prescription groups showed slower metabolism of spinosin and ferulic acid and higher bioavailability [88]. Qiao studied the pharmacokinetics of flavonoids from ZS in rats. The results showed that after oral administration, the blood drug concentration of $6^{\prime \prime \prime}$-feruloylspinosin and $6^{\prime \prime \prime}$-p-coumaroylspinosin reached a maximum after approximately $45 \mathrm{~min}$; however, the AUC, the clearance rate $(\mathrm{Ke})$, and the half-life $\left(T_{1 / 2}\right)$, among other parameters, were different. The two compounds followed a first-order kinetics elimination process in vivo [89].

In summary, the bioavailability of jujuboside A after intragastric administration was very low compared with intravenous administration; preliminary speculation may be that the numerous drugs are in the form of prototype or present in the gastrointestinal tract after some transformation. In addition, different combinations of drugs have different effects on the pharmacokinetics of ZS and its main components in rats; this may be due to the fact that certain components of different drugs affect the rate of absorption and elimination in the process of drug combination. These speculations require further research to support.

\section{Toxicology}

To date, ZS has been regarded as a traditional Chinese medicine with a high level of safety, and very few toxic reactions have been found in either dietary or clinical applications. According to the Chinese Materia Medica, ZS is toxic only at high doses. The dose of $150 \mathrm{~g} / \mathrm{kg}$ was given to mice by intragastric administration without toxic symptoms. Chronic toxicity test in rats showed that its toxicity was extremely low too. The lethal dose of intraperitoneal injection in mice was $14.33 \pm 2 \mathrm{~g} / \mathrm{kg}$ [8]. Sameena Alam et al. carried out an oral toxicity test on ZS root extract and showed that the extract $(2500 \mathrm{mg} / \mathrm{kg})$ had no toxicity or lethal effects in mice [90].

A study exploring the toxicological characteristics of a compound capsule of Gastrodiae Rhizoma and ZS found no toxic effects or animal deaths at the maximum dosage (30000 mg) of the sample after gavage. Genetic toxicity tests including the Ames test, the mouse bone marrow cell micronucleus test, and the mouse sperm malformation test all showed negative results. Therefore, the capsule has no genetic toxicity as per the scope of the above tests and thus should be further researched and developed [91]. Acute and subchronic toxicity tests of a ZS oral liquid $(500 \mathrm{mg} / \mathrm{mL})$ have also been carried out in chickens. No toxic effects were observed with either dosing regimen. The effect of the oral liquid on blood biochemical indexes was reversible in the subchronic toxicity test; thus, continuous oral administration was found to be safe in chickens [92].

Wang et al. injected different doses of an alcohol extract of ZS into the caudal vein of mice and found that some mice had a toxic reaction and died. The $\mathrm{LD}_{50}$ was $27.5 \mathrm{~g} / \mathrm{kg}$ with $95 \%$ confidence limits of $25.1-30.1 \mathrm{~g} / \mathrm{kg}$. An autopsy of the $d$ animals showed no pathological changes in their main organs. However, no mice died in 14 consecutive days of observation after gavage administration of $340 \mathrm{~g} / \mathrm{kg}$ of the same alcohol extract of ZS [93]. Therefore, ZS is considered a safe traditional Chinese medicine.

\section{Future Perspectives and Conclusions}

In summary, ZS is a traditional Chinese medicine especially used in Asian countries. Presently, numerous chemical constituents have been isolated and identified from this plant. Several experts have studied the plant and made significant contributions in several areas. However, new problems and challenges remain in the research of it. In particular, we need further research and exploration to meet clinical requirements.

First, as a traditional Chinese medicine, although ZS has been studied extensively in recent years, the research has mainly concentrated on saponins, flavonoids, alkaloids, and so on; the actions of fatty oils and other chemical components are rarely reported. However, some fatty oils also have good pharmacological activity. For example, ZS oil has good antioxidant properties, and it is one of the important material bases to reflect the efficacy of ZS [17]. Therefore, the development of ZS oil products has broad application prospects. Second, few studies have been performed to assess pharmacokinetics and toxicity. Researchers should pay more attention to this aspect. Researchers should also assess toxicity in vivo to improve drug safety, to allow for further drug development that should lay the foundation for future clinical drug use. In China, there is a shortage of supply in the market as the wild ZS sources are decreasing each day, and thus, some fake plants, such as Lizaoren, ZhiqiZi, Dianzaoren, and Bingdou, have appeared in the pharmaceutical market [94]. In addition, the shapes of some fruits are very similar to that of ZS, and thus, it is difficult to distinguish them by traditional identification methods. Recently, a PCR method based on the Internal Transcribed Spacer (ITS) sequence site has been developed that can differentiate ZS from its fake counterparts. This method uses primer ZmITS3 to amplify a $66 \mathrm{bp}$ fragment from ZS, but no such band can be amplified from the fake plants. Thus, ZmITS3 can be used as a specific primer to identify genuine ZS and we need further research in this aspect to improve the quality of medicinal materials [95]. Fourth, a growing number of people are suffering from 
insomnia and anxiety with the increasing pressure on people's life and work. However, the long-term use of sleeping pills not only impairs memory function and induces Alzheimer's disease but also leads to addiction and drug dependence. Patients who understand the concept of preventive medicine may be willing to move from drug treatment toward the use of functional foods derived from natural plant resources. ZS, as an important medicine for nourishing and calming the mind, could therefore be used as an alternative to prevent and treat insomnia.

This paper has systematically and comprehensively introduced the research status of ZS in recent years, including its botanical, and its traditional uses, phytochemical, pharmacological, pharmacokinetic, and toxicological characteristics. Although great progress has been made, several aspects are yet to be known.

We hope that this paper can provide some suggestions for future research directions of traditional Chinese medicine.

\section{Disclosure}

Su-Rong $\mathrm{He}$ and Chong-Bo Zhao are regarded as co-first authors.

\section{Conflicts of Interest}

The authors declare that there are no conflicts of interest.

\section{Authors' Contributions}

Su-Rong He and Chong-Bo Zhao contributed equally to this work. Surong He wrote the Introduction, Phytochemistry, and Pharmacology sections; Jingxia Zhang wrote the Pharmacokinetics and Toxicity sections; Jing Wang systemically revised the manuscript before submission; Bo $\mathrm{Wu}$ finalized the draft; Chunjie Wu and Chongbo Zhao designed the whole structure of the manuscript.

\section{Acknowledgments}

This work was funded by the National Natural Science Foundation of China (Program no. 81803732), Natural Science Basic Research Plan in Shaanxi Province of China (Program no. 2018JQ8022), Scientific Research Program of Shaanxi University of Chinese Medicine (Program no. 2017PY31), and Scientific Research Project of Shaanxi University of Chinese Medicine (Program no. 2020CX30).

\section{References}

[1] Z. Z. Qu, "History: types and utilization of Semen Ziziphi Spinosae," Journal of Agricultural University of Hebei, vol. 3, 1982.

[2] Q. H. Gao, C. S. Wu, and M. Wang, "The jujube (Ziziphus jujuba Mill.) fruit: a review of current knowledge of fruit composition and health benefits," Journal of Agricultural and Food Chemistry, vol. 61, no. 14, pp. 3351-3363, 2013.

[3] S. Z. Yin, H. K. Jin, B. Y. Jin, and S. G. Hong, "Study on alkaloids from Semen Ziziphi Spinosae," China Journal of Chinese Materia Medica, vol. 5, pp. 40-64, 1997.
[4] S. J. Liu, Z. S. Tang, C. L. Cui et al., "The research progress of chemical composition of SuanZaoRen," Western Journal of Traditional Chinese Medicine, vol. 29, no. 9, pp. 143-146, 2016.

[5] J. R. Shi, Y. Zhou, and P. Zhou, "General situation on Semen Ziziphi Spinosae," The Journal of Pharmaceutical Practice, vol. 22, no. 2, pp. 94-98, 2004.

[6] B. Y. Zen, B. Y. Li, and X. C. Li, "Study on present situation of traditional Chinese medicine ziziphi spinosi semen," Journal of Traditional Chinese Medicine University of Hunan, vol. 32, no. 12, pp. 74-75, 2012.

[7] S. X. Sun and C. J. Hu, "Study on the medical history and processing of Semen Ziziphi Spinosae," Journal of Chinese Medicinal Materials, vol. 9, pp. 25-28, 1993.

[8] X. Y. Sun, Sheng Nong's Herbal Classic, People's Medical Publishing House, Beijing, China, 1963.

[9] Chinese Pharmacopoeia Commission, Chinese Pharmacopoeia, Science and Technology Press of Shanghai, Shanghai, China, 2015.

[10] Chinese Flora Commission, Flora of China, Science Press, vol. 48, no. 1, Beijing, China, 1982.

[11] X. W. Cheng and X. X. Zhang, "Talking about the function of Semen Ziziphi Spinosae ancient to modern times," Chinese Journal of Management in Chinese Medicine, vol. 14, no. 11, pp. 66-68, 2006.

[12] Y. Chen and S. M. Chen, "Advances in clinical application and pharmacological experiments of wild jujube seed decoction," Shanxi Journal of Traditional Chinese Medicine, vol. 30, no. 12, pp. 41-43, 2014.

[13] C. X. Bi, "Current situation of resource utilization of Semen Ziziphi Spinosae," Shanxi Forest Science and Technology, vol. 1, pp. 49-52, 2000.

[14] H. Otsuka, T. Akiyama, K. I. Kawai, S. Shibata, O. Inoue, and Y. Ogihara, "The structure of jujubosides A and B, the saponins isolated from the seeds of Zizyphus jujuba," Phytochemistry, vol. 17, no. 8, pp. 1349-1352, 1978.

[15] S. W. Won, S. K. Sam, H. S. Sang et al., "The structure of spinosin (2"-O- $\beta$-glucosylswertisin) from Zizyphus vulgaris var. Spinosus," Phytochemistry, vol. 18, no. 2, pp. 353-355, 1979.

[16] L. Zeng, R. Y. Zhang, and X. Wang, "Studies on chemical constituents of Semen Ziziphi Spinosae," Journal of Integrative Plant Biology, vol. 5, pp. 517-522, 1986.

[17] J. R. Wan, J. Zhang, Z. Q. Yin, J. Y. Liang, and W. C. Ye, "Chemical constituents from the seeds of Ziziphus jujuba var. spinosa," Chinese Journal of Natural Medicines, vol. 4, pp. 268-270, 2008.

[18] Q. Cao and K. W. Wang, "Studies on the chemical constituents of the seeds of Zizyphus jujuba mill," Journal of Pharmaceutical Practice, vol. 27, no. 3, pp. 209-213, 2009.

[19] H. Y. Zhu, L. N. Zhnag, S. Tang et al., "Determination of spinosin, jujubosides A and B in Ziziphi Spinosae Semen from three different origins," Chinese Journal of Pharmaceutical Analysis, vol. 35, no. 12, pp. 2099-2104, 2015.

[20] Z. D. Wang, C. Y. Xu, and L. Xie, "Study on chemical constituents of wild jujube fatty oil extracted by supercritical $\mathrm{CO}_{2}$ extraction," Chinese Traditional and Herbal Drugs, vol. 32, no. 11, pp. 976-977, 2001.

[21] C. Y. Wang, D. Y. Hou, R. H. Hui, X. Y. Liu, and Y. Q. Zhu, "Analysis of fatty acids in seed of Zizyphus jujuba Mill by GC/ MS," LiShiZhen Medicine and Materia Medica Research, no. 1, pp. 62-63, 2006.

[22] Y. Che, S. T. Li, and Y. Q. Zhang, "Study on chemical composition of supercritical extraction products from 
Ziziphus jujuba," Journal of Anhui Agricultural Sciences, vol. 37, no. 17, pp. 7822-7834, 2009.

[23] K. Lu, L. L. Zhang, M. Wang, Y. L. Bi, S. S. Sang, and L. Ma, "Physicochemical properties and fatty acid compositions of jujube kernel oil," China Oils and Fats, vol. 8, pp. 70-72, 2006.

[24] Y. Ding, J. B. Xie, and Y. Q. Zhang, "Culture supernatant of mice consuming polysaccharides from Ziziphus jujuba Mill var. Spinosa seeds on the expression of absorption-related proteins in caco-2 cells [J/OL]," Science and Technology of Food Industry:, vol. 1-9, 2020.

[25] L. F. Li, K. Zhang, S. X. Wu, and L. J. Fu, "Determination of polysaccharides in Semen Ziziphi Spinosae," Hebei Journal of Traditional Chinese Medicine, vol. 4, pp. 20-21, 1996.

[26] T. T. Lin, L. L. Fang, Y. X. Zhang et al., "Optimization of decoloration process of Zizyphi Spinosae Semen polysaccharide by response surface methodology," Science and Technology of Food Industry, vol. 39, no. 24, pp. 198-208, 2018.

[27] T. T. Lin, Extractionand Preparation of Polysaccharide from Ziziphi Spinosae Semen and its Immunomodulatory Activity, Tianjin University of Commerce, Tianjin, China, 2018.

[28] S. M. Guo, X. W. Fan, and S. G. Song, "Extraction, separation and identification of ferulic acid from Semen Ziziphi Spinosae," Northwest Pharmaceutical Journal, vol. 1, pp. 22-23, 1995.

[29] B. H. Han, M. H. Park, and Y. N. Han, "Cyclic peptide and peptide alkaloids from seeds ofZizyphus vulgaris," Phytochemistry, vol. 29, no. 10, pp. 3315-3319, 1990.

[30] Z. R. Zhang, F. Q. Zhou, Q. Zhan, J. X. Li, and L. J. Wang, "Analysis of trace elements and amino acids in Semen Ziziphi Spinosae from Shandong province, China," Studies of Trace Elements and Health, vol. 3, pp. 32-33, 1997.

[31] L. S. Dong, R. Guo, and Y. M. Xu, "Determination of phosphatidylcholine in Semen Ziziphi Spinosae by HPLC," Journal of Guiyang College of Traditional Chinese Medicine, vol. 4, pp. 59-60, 1993.

[32] L. J. Wang, Y. Q. Zhang, Y. Wang, Z. T. Deng, and X. L. Wang, "Effects of semen flavonoids on ability of learning and memory in mice with memory disorder," Chinese Journal of Information on Traditional Chinese Medicine, vol. 21, no. 5, pp. 53-60, 2014.

[33] H. E. Lee, S. Y. Lee, J. S. Kim et al., "Ethanolic extract of the seed of zizyphus jujuba var. spinosa ameliorates cognitive impairment induced by cholinergic blockade in mice," Biomolecules and Therapeutics, vol. 21, no. 4, pp. 299-306, 2013.

[34] Y. Q. Zhang, L. D. Qiao, M. Y. Song, L. J. Wang, J. B. Xie, and H. Feng, "HPLC-ESI- MS/MS analysis of the water-soluble extract from Ziziphi Spinosae Semen and its ameliorating effect of learning and memory performance in mice," Pharmacogn Magazine, vol. 10, no. 40, pp. 509-516, 2014.

[35] J. P. Hou, E. H. Zhang, Y. Hu, and T. Sun, "The effect of Ziziphi Spinosae Semen on learning and memory ability of mice," Journal of Guangxi College of Traditional Chinese Medicine, vol. 3, pp. 11-13, 2002.

[36] S. L. Wu, B. X. Yuan, and Z. Y. Ma, "Effect of Ziziphi Spinosae Semen oil on learning and memory ability in mice," Chinese Traditional and Herbal Drugs, vol. 3, pp. 56-57, 2001.

[37] J. Zhu, Y. F. Cai, H. F. Yuan, and X. Wang, "Effect of jujuboside on the cognitive dysfunction of alzheimer disease in rats," Journal of Jiangxi University of Traditional Chinese Medicine, vol. 29, no. 5, pp. 74-76, 2017.

[38] X. Y. Wang and Y. Y. Zhang, "Observation on sedative and analgesic effects of Semen Ziziphi Spinosae in mice," Modern Animal Husbandry Science \& Technology, vol. 2, pp. 229-231, 2014.
[39] Q. Y. You, P. Wang, C. P. Zhang, and L. L. Wu, "Research on sedative and hypnotic effect of long gu and SuanZaoren," Journal of Liaoning University of Traditional Chinese Medicine, vol. 5, pp. 28-29, 2007.

[40] L. M. Sun and L. Zhang, "Study on sedation and hypnosis of water extract from Semen Ziziphi Spinosae," Journal of Jilin Agricultural Science and Technology University, vol. 21, no. 2, pp. 1-3, 2012.

[41] L. H. Zhao, W. Qiao, and L. Xu, "Experimental study on anticonvulsion effect of alkaloids from semen zizyphi spinosae," Tianjin Pharmacy, vol. 1, pp. 4-5, 2007.

[42] C. H. Shou, J. Wang, X. X. Zheng, and D. W. Guo, "Inhibitory effect of jujuboside A on penicillin sodium induced hyperactivity in rat hippocampal CA1 area in vitro," Acta Pharmacologica Sinica, vol. 22, no. 11, pp. 986-990, 2001.

[43] M. Zhang, G. Ning, C. Shou, Y. Lu, D. Hong, and X. Zheng, "Inhibitory effect of jujuboside A on glutamate-mediated excitatory signal pathway in Hippocampus," Planta Medica, vol. 69, no. 8, pp. 692-695, 2003.

[44] D. Zhang, B. X. Yuan, and H. Sun, "The effect of jujuboside on rats with spontaneous hypertension," Journal of Xi'an Jiaotong University (Medical Sciences), vol. 24, pp. 59-60, 2003.

[45] X. Y. Liu and Y. Zhao, "Hypotensive effect of total saponins of semen zizyphi spinosae on essential hypertension rats," Heilongjiang Science and Technology Information, vol. 14, p. 55, 2012.

[46] Y. L. Wu, "Effect of total saponins in processed semen zizyphi spinosae on experimental animal model of hyperlipidemia in rats," Jiangsu Journal of Traditional Chinese Medicine, vol. 5, pp. 55-57, 2004.

[47] S. X. Wu, L. F. Li, X. C. Lang et al., "Experimental study on hypolipidemic and antiplatelet aggregation effects of jujube kernel oil and jujube extract," China Journal of Chinese Materia Medica, no. 7, pp. 435-449, 1991.

[48] Q. Liu, J. M. Guo, and H. Y. Sun, "Effect of jujube kernel oil on blood lipid in rabbits," Modern Practical Medicine, vol. 8, p. 426, 2002.

[49] W. Zhang, B. X. Yuan, X. J. Yu, H. Sun, and C. T. Xia, "Protective action of Semen Ziziphi Spinosae and on acute myocardial ischemia," Journal of Xi'an Jiaotong University (Medical Sciences), vol. 4, pp. 333-335, 2005.

[50] Y. L. Wu, "Anti-myocardial ischemia effect of total saponins in processed Semen Ziziphi Spinosae," Journal of Nanjing University of Traditional Chinese Medicine, vol. 3, pp. 187189, 2004.

[51] J. F. Liu, W. X. Gu, S. L. Yang, and X. M. Liu, “Antiarrhythmic and myocardial ischemic effects of semen ZiziphiSpinosae in rats," Journal of First Military Medical University, vol. 1, pp. 31-33, 1985.

[52] Y. S. Huang, Protective Effect and Mechanism of Jujuboside A on Myocardial Ischemia-Reperfusion in Rats, Doctoral dissertation, Southern Medical University, Guangzhou, China, 2011.

[53] S. R. Xu, J. Y. Tao, Q. L. Tian et al., "Experimental observation on antiarrhythmic activity of extract from Semen Ziziphi Spinosae," Chinese Traditional and Herbal Drugs, vol. 18, no. 12, pp. 18-20, 1987.

[54] J. Z. Wan and Y. H. Huang, "Study on preventing acute high altitude reaction with Semen Ziziphi Spinosae," Pharmacology and Clinics of Chinese Materia Medica, p. 215, 1985.

[55] Y. S. Zhang, X. J. Chen, C. L. Yu, J. F. Liu, and H. Y. Pan, "Protective effect of total saponins of Semen Ziziphi Spinosae on hypoxia in mice and effects of total saponins of Semen Ziziphi Spinosae on platelet aggregation and thromboxane $B_{2}$ 
production in rabbits in vitro," Journal of High Altitude Medicine, no. 2, pp. 6-8, 1991.

[56] Z. Z. Hu, Z. Y. Cai, and J. Zhu, "Methanol extract of Zizyphi Spinosi semen increases the REM sleep of daytime associated modulation mechanism," Journal of Nanjing University of Traditional Chinese Medicine, vol. 29, no. 3, pp. 238-242, 2013.

[57] Y. L. Wu, H. Q. Xu, and S. Chen, "Comparative studies on the sedative and hypnotic effect of the crude and processed semen of ziziphi spinosa, and the effect of total flavonoid and saponin," LiShizhen Medicine and Materia Medica Research, vol. 9, pp. 868-869, 2005.

[58] B. L. Li, C. T. Xia, and B. X. Yuan, "Sedative and hypnotic effects of oil of spine date seeds from different extraction technologies in mice," Journal of Xi'an Jiaotong University (Medical Sciences), vol. 29, no. 2, pp. 227-229, 2008.

[59] J. G. Jiang, X. J. Huang, J. Chen, and Q. S. Lin, "Comparison of the sedative and hypnotic effects of flavonoids, saponins, and polysaccharides extracted from Semen Ziziphus jujube," Natural Product Research, vol. 21, no. 4, pp. 310-320, 2007.

[60] B. H. Han, M. H. Park, and J. H. Park, "Chemical and pharmacological studies on sedative cyclopeptide alkaloids in some Rhamnaceae plants," Pure and Applied Chemistry, vol. 61, no. 3, pp. 443-448, 1989.

[61] Y. Jia, Y. F. Guo, and S. J. Sun, "Study on sedative and hypnotic effects of volatile oil from Semen ZiziphiSpinosae by supercritical $\mathrm{CO}_{2}$ : extraction," Chinese Journal of Traditional Chinese Medicine, vol. 33, no. 9, pp. 447-449, 2018.

[62] B. Adzu, S. Amos, S. Dzarma, C. Wambebe, and K. Gamaniel, "Effect of Zizyphus spina-christi Willd aqueous extract on the central nervous system in mice," Journal of Ethnopharmacology, vol. 79, no. 1, pp. 13-16, 2002.

[63] P. Y. Li, "Study on the effect of sedative and hypnotic of spina date seed on mice," Medical Journal of Chinese People's Health, vol. 23, no. 21, pp. 2627-2630, 2011.

[64] X. Y. Liu, M. Y. Liu, H. S. Bian, and T. L. Li, "Dose-effect and time-effect of jujuboside A in Drosophila sleep," Journal of Changchun University of Chinese Medicine, vol. 32, no. 5, pp. 905-907, 2016.

[65] Y. Hua, Study on Antianxiety Effect of Semen Zizyphi Spinosae on Rat Based on Information Encoding in Basolateral Amygdla, Heilongjiang University of Chinese Medicine, Harbin, China, 2018.

[66] M. J. Guo, Study on the Effect of Genuine Semen Zizyphi Spinosae to the Anxiety Behavior in the Yin-Deficiency Rats and the Body Distribution of Major Components, Henan College of Traditional Chinese Medicine, Henan, China, 2014.

[67] C. L. Rong, Y. X. Dai, and Y. Cui, "Effect of semen zizyphi spinosae on the anxiety behavior of the yin-deficiency mice," Journal of Chinese Medicinal Materials, vol. 31, no. 11, pp. 1703-1705, 2008.

[68] W. H. Peng, M. T. Hsieh, Y. S. Lee, Y. C. Lin, and J. Liao, "Anxiolytic effect of seed of Ziziphus jujuba in mouse models of anxiety," Journal of Ethnopharmacology, vol. 72, no. 3, pp. 435-441, 2000.

[69] D. Zhang, Y. Li, J. Wang, M. Wang, and Y. Wang, "Study on antidepression effect of active ingredients in Semen Ziziphi Spinosae," Journal of Shanxi College of Traditional Chinese Medicine, vol. 14, no. 05, pp. 16-18, 2013.

[70] Q. D. Zhao, L. X. Shu, and Y. Wang, "Study on the antidepressant effect of total flavonoids from Semen Ziziphi Spinosae," Tianjin Journal of Traditional Chinese Medicine, vol. 28, no. 4, pp. 335-337, 2011.
[71] Q. D. Zhao, L. X. Shu, L. Wang, J. J. Mou, Z. G. Song, and J. M. Li, "Antidepressant effect of total saponins from Semen Ziziphi Spinosae," Central South Pharmacy, vol. 9, no. 7, pp. 489-491, 2011.

[72] T. L. Zhu, Z. S. Hu, and L. Li, "Study on the antidepressant effect of active fraction from semen zizyphi spinosae," Acta Academiae Medicinae, vol. 18, no. 5, pp. 420-422, 2009.

[73] S. J. Bao, S. F. Li, G. Q. Han, and M. Nie, "Anti-inflammatory effect of Semen Ziziphi Spinosae," Journal of Guiyang Medical College, vol. 19, pp. 336-338, 1994.

[74] X. Zhao, S. T. Zhang, C. M. Liu, T. X. Yan, F. Xiao, and Y. Jia, "Study on purification technology for total flavonoids from the seeds of Ziziphus jujuba Mill. With macroporous resins and in vitro antioxidant ability," Science and Technology of Food Industry, vol. 37, no. 24, pp. 278-282, 2016.

[75] C. Lang, M. X. Li, S. X. Wu, B. Y. Jia, L. F. Li, and S. Y. Zhao, "Experimental study on the enhancement of immune function in mice by Semen Ziziphi Spinosae," China Journal of Chinese Materia Medica, vol. 11, pp. 43-64, 1988.

[76] T. Mishra and A. Bhatia, "Augmentation of expression of immunocytes' functions by seed extract of Ziziphus mauritiana (Lamk.)," Journal of Ethnopharmacology, vol. 127, no. 2, pp. 341-345, 2010.

[77] T. Lin, Y. Liu, C. Lai, T. Yang, J. Xie, and Y. Zhang, "The effect of ultrasound assisted extraction on structural composition, antioxidant activity and immunoregulation of polysaccharides from Ziziphus jujuba Mill var. spinosa seeds," Industrial Crops and Products, vol. 125, pp. 150-159, 2018.

[78] Q. L. Wang, B. X. Yuan, Q. M. Gao, J. H. Huang, W. Gao, and A. F. Liu, "Effects of jujube kernel oil on survival and body weight of mice with Ehrlich's ascites carcinoma," Journal of Xi'an Jiaotong University (Medical Sciences), vol. 3, pp. 295297, 1995.

[79] Z. Peng, H. Zhang, S. Chen, and W. Guo, "Protective effect of Semen Ziziphi Spinosae on the decrease of SOD in mice feverish with endotoxin," China Journal of Chinese Materia Medica, vol. 20, no. 6, pp. 369-370, 1995.

[80] X. Huang, A. Kojima-Yuasa, T. Norikura, D. O. Kennedy, T. Hasuma, and I. Matsui-Yuasa, "Mechanism of the anticancer activity of Zizyphus jujuba in HepG2 cells," The American Journal of Chinese Medicine, vol. 35, no. 3, pp. 517-532, 2007.

[81] X. Kennedy, A. Kojima-Yuasa, S. Xu, D. O. Kennedy, T. Hasuma, and I. Matsui-Yuasa, "Combination of Zizyphus jujuba and green tea extracts exerts excellent cytotoxic activity in HepG2 cells via reducing the expression of APRIL," The American Journal of Chinese Medicine, vol. 37, no. 1, pp. 169-179, 2009.

[82] T. T. Kennedy, X. T. Zhao, Y. Q. Zhang, J. B. Xie, and A. M. Zhou, " 6 "'-Feruloylspinosin alleviated beta-amyloid induced toxicity by promoting mitophagy in Caenorhabditis elegans (GMC101) and PC12 cells," Science of the Total Environment, vol. 715, 2020.

[83] X. Zhang, F. S. Chen, and H. Zhang, "The antioxidant activity of active polypeptide from semen oil," Henan Science, vol. 32, no. 3, pp. 347-351, 2014.

[84] C. Liu, Y. Li, Y. Zhong et al., "An LC-MS/MS method for determination of jujuboside $\mathrm{A}$ in rat plasma and its application to pharmacokinetic studies," Journal of Chromatography B, vol. 899, pp. 21-26, 2012.

[85] Y. Zhang, J. B. Xie, and Y. Q. Zhang, "Determination of jujuboside $\mathrm{A}$ in rat plasma by HPLC-MS/MS and its pharmacokinetics study," Food Research and Development, vol. 36, no. 3, pp. 110-114, 2015. 
[86] C. Wang, Study on Extraction of Jujubosides and Absorption of Jujubosides in Rats, Tianjin University of Commerce, Tianjin, China, 2011.

[87] X. Zheng, X. Yang, Q. Le, S. Zhang, R. Chen, and Z. Xiang, "Development and validation of an UPLC-MS/MS method for determination of jujuboside B in rat plasma and its application in pharmacokinetic and bioavailability studies," Analytical Methods, vol. 7, no. 10, pp. 4049-4054, 2015.

[88] R. Gao, S. Li, X. J. Chen, X. F. Wang, S. X. Wang, and M. F. Fang, "Pharmacokinetic effect of combined administration on spinosin and ferulic acid in monarch drug ziziphi spinosae semen kernel," China Journal of Chinese Materia Medica, vol. 40, no. 16, pp. 3293-3297, 2015.

[89] L. .,D. Qiao, Preparation of Semen Ziziphi Spinosae Flavonoids-Loaded Solid Lipid Nanoparticles and its Pharmacokinetics, Tianjin University of Commerce, Tianjin, China, 2016.

[90] S. Zhang, M. S. Hussain, M. K. Reddy, M. V. Reddy, and R. K. Gupta, "Antiulcer and antioxidant potential of Zizyphus jujuba Mill root extract in aspirin and ethanol induced gastric ulcers," International Journal of Phytomedicine, vol. 8, no. 2, pp. 0975-0185, 2016.

[91] G. L. Yuan, L. Jiang, G. L. Yin, and Y. Y. Huang, "Toxicological safety study of Gastrodiae rhizoma-semen ZiziphiSpinosae capsule," Journal of Food Safety \& Quality, vol. 4, no. 5, pp. 1408-1414, 2013.

[92] Y. C. Li, F. M. Zhang, and C. He, "Studies on the acute and sub-chronic toxicity of suanzaoren solution," Chinese Veterinary Science, vol. 40, no. 9, pp. 978-983, 2010.

[93] L. J. Wang, M. C. Zhang, and C. Yan, "Experimental study on acute toxicity of Semen Ziziphi Spinosae extract," Lishizhen Medicine and Materia Medica Research, vol. 20, no. 7, pp. 1610-1611, 2009.

[94] J. Q. Li, "Identification of Semen Ziziphi Spinosae from semen zizyphus mauritiana, lens culinaris and HoveniaDulcisThunb," Guangming Journal of Chinese Medicine, vol. 29, no. 3, pp. 491-493, 2014.

[95] G. L. Li, Y. D. Song, Z. H. Lu, C. H. Liu, J. Li, and X. N. Zhang, "Identification of zizyphus jujuba with the counterfeit products by allele-specific PCR based on ITS genes sequenced," Modern Chinese Medicine, vol. 18, no. 12, pp. 1566-1570, 2016. 